DIW BERLIN

Discussion

Papers

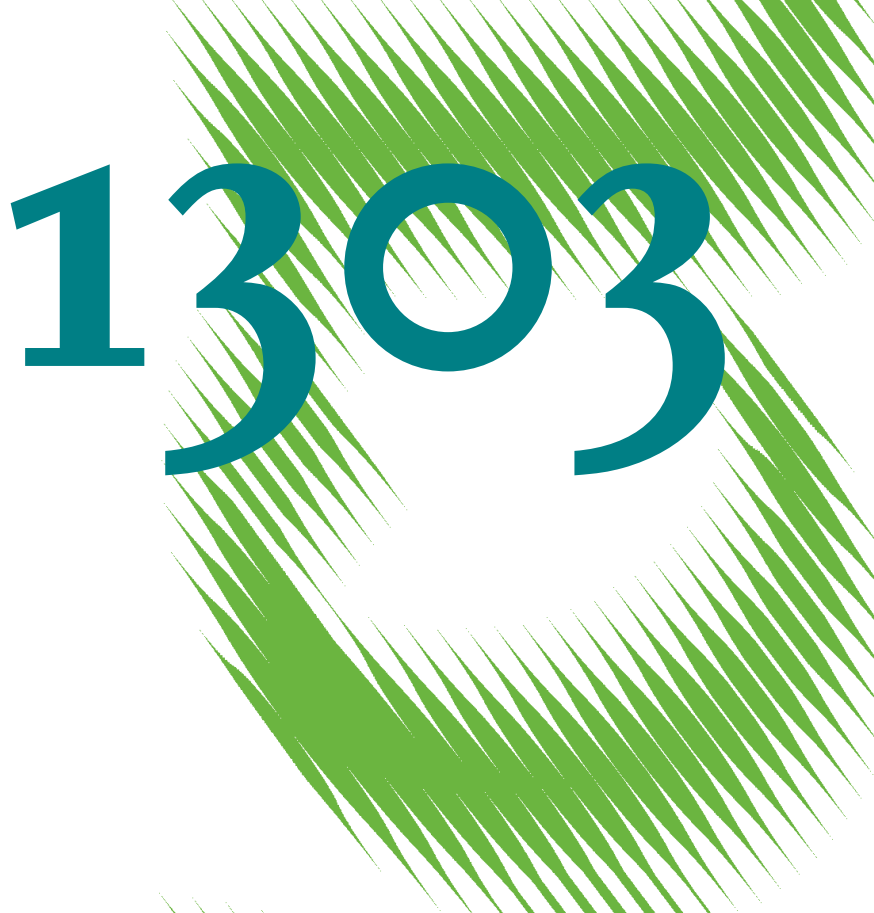

Has German Business Income Taxation Raised Too Little Revenue Over the Last Decades? 
Opinions expressed in this paper are those of the author(s) and do not necessarily reflect views of the institute.

IMPRESSUM

(C) DIW Berlin, 2013

DIW Berlin

German Institute for Economic Research

Mohrenstr. 58

10117 Berlin

Tel. $+49(30) 89789-0$

Fax +49 (30) $89789-200$

http://www.diw.de

ISSN print edition $1433-0210$

ISSN electronic edition 1619-4535

Papers can be downloaded free of charge from the DIW Berlin website:

http://www.diw.de/discussionpapers

Discussion Papers of DIW Berlin are indexed in RePEc and SSRN:

http://ideas.repec.org/s/diw/diwwpp.html

http://www.ssrn.com/link/DIW-Berlin-German-Inst-Econ-Res.html 


\title{
Has German Business Income Taxation Raised Too Little Revenue Over the Last Decades?
}

\author{
Stefan Bach \\ DIW Berlin
}

May 22, 2013

\begin{abstract}
This study presents comprehensive macroeconomic measures on the revenue from business taxation in Germany. A comparison of the tax base reported in tax statistics with the corporate income derived from national accounts gives hints to considerable tax base erosion. The high weight of reported tax losses underlines this result. The average implicit tax rate on corporate income was around 21 percent since 2001, and thus falling considerably short of statutory tax rates and effective tax rates discussed in the literature. For lack of detailed accounting data it is hard to give precise reasons for the presumptive tax base erosion.
\end{abstract}

Keywords: Business income taxation, implicit tax rates, tax base erosion

JEL Classification: H25, H26, H22

Acknowledgement: The author thanks Hermann Quinke, Norbert Schwarz, Hermann Buslei, Nadja Dwenger, Frank Fossen, and participants in seminars for helpful information, comments and suggestions. The usual disclaimer applies.

DIW Berlin - German Institute for Economic Research. 10108 Berlin. Germany. 


\section{Introduction}

The impact of business taxation on tax revenue, location attractiveness, and economic performance has been under extensive debate in Germany for decades. Traditionally, the German corporate income tax was highly integrated into the taxation of personal income. This was reflected by the full imputation system, which lasted until 2001. The standard rate of the corporate income tax was oriented to the top rate of the personal income tax. Income from partnerships and self-employed income liable to the personal income tax were levied at rising marginal tax rates due to the income tax progression. In addition, the local business tax largely turned to a tax on business income since decades. Putting together all these taxes, business income in Germany was taxed at relative high statutory tax rates, at least up to 2007. Likewise, measures of effective tax rates, derived from simulation models following the approaches of King and Fullerton (1984) and Devereux and Griffith (1999, 2003), indicate rather high levels of business taxation in Germany compared to other countries.

At the same time, at least since the mid-nineties, there was a rising public sentiment in Germany that the revenue from business taxation lags behind economic performance and business income growth. The revenue of the corporate income tax relative to GDP decreased, notably in relation to corporate income. Investment incentives for East Germany via tax allowances and tax credits, tax competition in the course of globalization and European integration, and repercussions of major tax reforms seemed to impair business tax revenue. Anecdotal evidence on tax-saving strategies of firms and top-earning individuals was increasingly spread by the media.

However, there is scarce empirical evidence that gives a clear picture of the economic issues involved. Current annual tax revenues do not necessarily give a reliable picture of the effective tax liabilities accrued in single years. Moreover, partnerships play an important role in Germany as even bigger firms use this legal form. The respective share of business taxation in personal income tax revenue is not to be isolated from revenue statistics because it is mingled with revenue from other sources of taxable income. Not least, the local business tax has a high revenue impact on overall business taxation in Germany. As it is deemed as a local charge for public infrastructure that is passed to output prices, it is often disregarded in the context of the entire business taxation.

In this study, we present comprehensive measures of the entire business taxation revenue and the tax base accrued in single tax years for Germany up to 2008. We use data from the busi- 
ness tax statistics that collect the relevant information from the tax returns. Based on a similar concept of the European Commission (2013), we derive a corporate income aggregate from the national accounts statistics that approximates the actual taxable income as close as possible. Dividing the tax revenue by the underlying macroeconomic income aggregate, we calculate macroeconomic implicit tax rates on corporate income.

We find that the implicit tax rates on corporate income falling considerably short of statutory tax rates and of effective tax rates discussed in the literature. Our estimations suggest that the average implicit tax rate on German corporate income was around 21 percent since 2001. A detailed comparison of the corporate income measured in national accounts with the corporate tax base reported in the tax statistics reveals a considerable gap that amounts to 4 percent of GDP and more in 2004. The gap has increased over the years up to 2007. For 2008, there is a marked decline due to the broadening of the tax base involved by the 2008 reform of business taxation. However, the gap still amounts to Euro 90 billion or 3.7 percent of GDP. This gives hints to considerable tax base erosion in Germany, although some estimation risks should be considered with the corporate income derived from national accounts. This result is emphasized by the high weight of losses reported in tax statistics. Due to the lack of reliable data from tax and financial accounting it is hard to give precise reasons for the presumptive tax base erosion and the high tax losses.

In the following Section 2, we give an overview on business income taxation in Germany and its main reforms over the last decades. Section 3 presents the tax revenue and the tax base of German business taxation accrued in selected years for which tax statistics are available. This information is compared with the respective macroeconomic figures derived from national accounts, in order to estimate macroeconomic implicit tax rates and dimensions of tax base erosion. Section 4 looks closer to the importance of losses by industrial composition and discusses some reasons of the presumptive tax base erosion with respect to the determination of taxable income, tax avoidance strategies, and inflation. Section 5 concludes.

\section{Business Income Taxation in Germany}

Germany's business income taxation comprises the local business tax (“Gewerbesteuer”), the corporate income tax, the personal income tax on income from unincorporated firms as well as on dividends distributed from corporations to individuals, and the solidarity surcharge, which is levied on both corporate and personal income tax liabilities. Box 1 at the end of this section summarizes the main reforms over the last two decades. 
An outstanding tradition of the German business taxation is its high weight on local taxation. The local business tax accounts for 40 percent of the entire business tax revenue paid from corporate business income (see below, Section 3.1). Historically levied on a broader base of the firm's value added and equity, it has been widely transformed to an extra tax on business income over the last decades. For historical reasons, the local business tax exempts farmers, liberal professions such as physicians, lawyers, architects, and journalists, as well as unincorporated "private” real estate and portfolio management. The main source of the tax base today is the operating profit attributed to the local jurisdiction. It is augmented by parts of the financing expenses, which represent the remainder of the former comprehensive business income taxation. The local municipalities apply their own tax rate to the firms' local tax base. The marginal tax rates relating to taxable income ranged from a minimum rate of 9 percent to almost 20 percent in agglomerations by 2007, the average rate was about 16 percent. The statutory tax rates have been reduced to about 14 percent on average as of 2008. Sole proprietors and partners of unincorporated firms benefit from a tax-free basic allowance. Moreover, since 2001 these firms are allowed to credit the local business tax liability up to a certain cap against their personal income tax liability. Therefore, the local business tax falls mainly on corporations.

With respect to the corporate income tax, Germany was running a full imputation system until 2001. Received dividends were part of the taxable income, and double taxation was ruled out by crediting the domestic corporate income tax falling on dividend income against the tax liability, both for the corporate and personal income tax. There was a two-tier tax rate distinguishing between retained profits (40 percent at last) and distributed profits (30 percent at last). In 2001/02, the full imputation system was replaced by a classical system with a uniform tax rate of 25 percent (15 percent as of 2008). Double taxation of dividends distributed within the corporate sector is now avoided by tax exemption, both for dividends from domestic corporations and from abroad. The personal income tax base includes only one half of the dividend income received. This "half-income-procedure" was discarded in 2009 when a final withholding taxation of capital income has been introduced with a flat rate of 25 percent, regardless of the shareholder's individual tax rate depending from individual taxable income.

The business income of the self-employed is liable to the personal income tax. This also applies to the entire income of partnerships, both distributed and retained. This income is taxed "transparently", which means that for tax assessment it is passed to their shareholders, who have to enter it into their tax return. Partnerships play an important role in Germany since many medium-sized businesses and even bigger firms use this legal form. They account for 
about 40 to 50 percent of the entire corporate tax base in Germany during the last decades (see below, Section 3.3). Thus, a considerable part of the business income tax revenue stems from the personal income tax, although sole proprietors and partners of unincorporated firms credit most of their local business tax liability against their personal income tax liability.

The solidarity surcharge is levied on the corporate and personal income tax liability as well as on withholding taxes on capital and wage income associated with the income taxation system. The surcharge was introduced by the federal government in order to raise funds for the hike in public expenditure and deficits that ran up in the course of the German reunification after 1990. The surcharge rate was 3.75 percent 1991-92, 7.5 percent 1995-97, and 5.5 percent since 1998.

Figure 1 Statutory tax rates on corporate income in international comparison, 1982-2013

Company/subsidiary level, excluding taxation of distributed profits at the shareholder level, including sub-central and local government business income tax rates in percent of taxable income

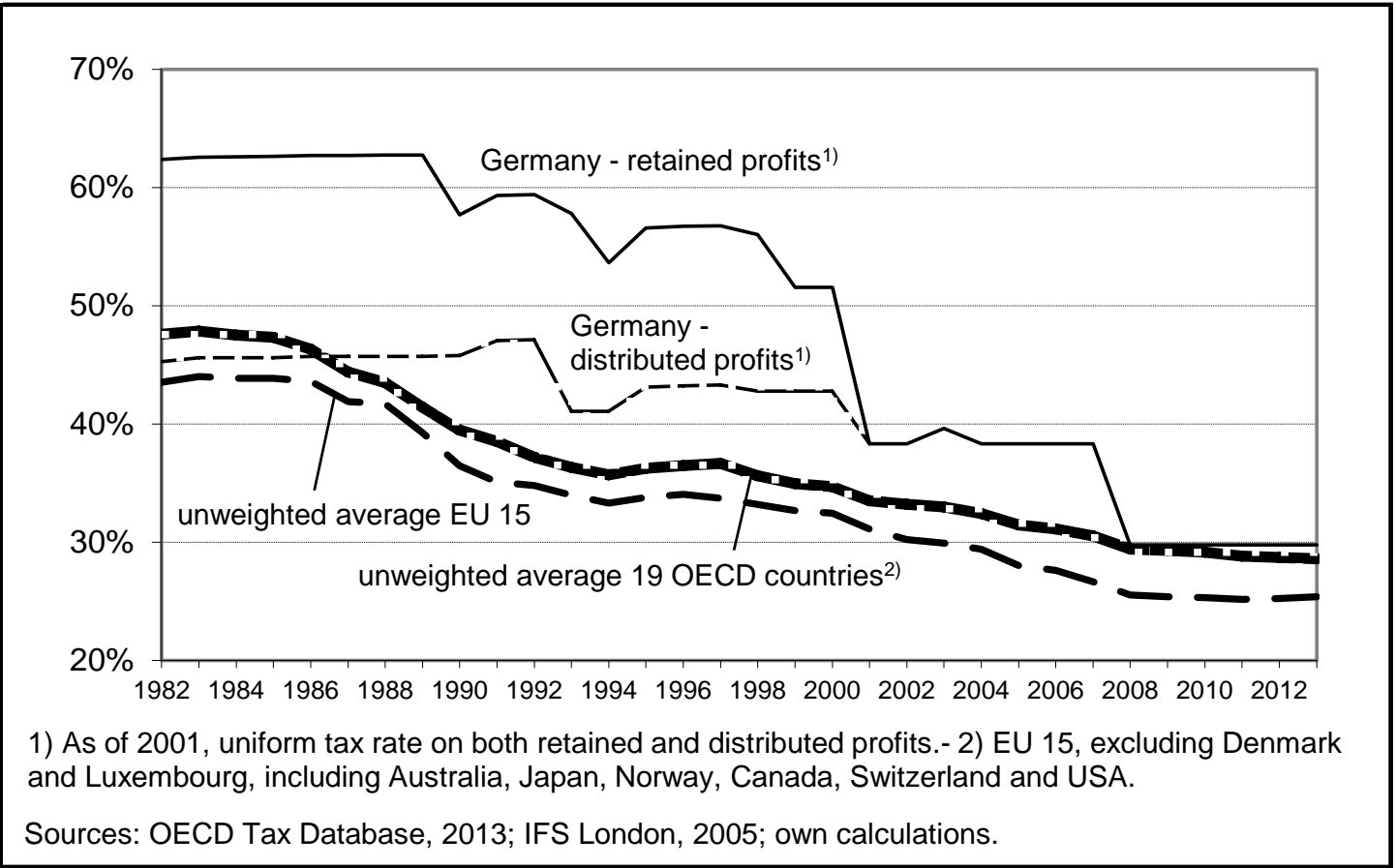

If we look at the combined corporate income tax rate in Germany compared with the average level of the EU 15 or the main OECD countries (Figure 1), the level of statutory tax rates was rather high over the last decades. The comparatively high tax rates remained up to 2007. In particular, the corporate tax rate on retained profits was high under the former full imputation system. It was oriented to meet the top rate of the personal income tax. The tax was reduced to the lower rate when current profits or retained reserves were distributed to the shareholders. In the course of internationalization and enhanced tax competition the high tax rates have 
been lowered step by step (see Box 1 at the end of this section). However, most of the European neighbor countries lowered their corporate income tax rates as well, and in many cases much stronger. As Figure 1 points out, the unweighted average tax rates on corporate income in the EU 15 decreased from 44 percent at the mid-eighties to 25 percent in 2011. The new member states in Eastern Europe apply tax rates around 10 to 19 percent. Even after the major reform of 2001/02, which lowered the combined tax rate to about 38.5 percent, Germany stood out for the highest tax rates in Europe. Only locations in oversee such as Japan or many agglomerations in the United States levied higher tax rates (OECD Tax Database, 2013). Only with the 2008 business tax reform Germany significantly reduced its combined tax rate to about 30 percent tax rates, which was around the average of the Western OECD countries.

The personal income tax rates in Germany have been reduced several times during the last two decades (Figure 2). Germany applies a formula schedule with monotonously increasing marginal tax rates for taxable income exceeding the basic allowance. The top rate, which is of particular interest for business and capital income taxation, was reduced from 53 percent in 1990 to 42 percent as of 2005. For income from business enterprise liable to the local business tax the top income tax rate was reduced to 47 percent for the years 1994-98, and to 45 percent for 1999-2000. The tax credit for the local business tax replaced this top rate limitation since 2001. As of 2007, a second top rate of 45 percent for the "rich" is levied on taxable income exceeding Euro 250,000. Since 2007, the personal income tax schedule remains largely the same, though it has been shifted somewhat to the right to adjust nominal income growth. It should be noted further that the solidarity surcharge increases the effective marginal tax rates (by 5.5 percent since 1998). ${ }^{1}$

As it is widely discussed in the literature as well as in the public debate, for measuring the effective tax burden one has to account for the differences between taxable income and the "true" economic income. Compared to financial investments, real investments often provide beneficial tax treatments and allow for tax avoidance strategies. Income determination rules and tax enforcement were considered to be rather generous in the case of business and capital income taxation in Germany up to the end of the nineties (see OECD, 1991, Ruding Report, 1992). Presumably, this was particularly the case with respect to provisions, depreciation allowances, the treatment of capital gains and losses, group taxation, the transfer of hidden re-

1 For instance, the 2005 top income tax rate of 42 percent is increased by 2.3 percent (42 percent times the surcharge rate of 5.5 percent). 
serves to other assets, and the deduction of losses carried forward or back from other tax years. Moreover, massive investment incentives for East Germany via generous tax allowances and tax credits have been introduced in the nineties. At the same time, the then advance in economic internationalization might have made German business taxation vulnerable to international tax competition and tax avoidance strategies of multinational firms or investors respectively. This is plausible in light of the high statutory tax rates in international comparison at that time. The pertinent strategies of multinational companies are profit shifting by transfer pricing, thin capitalization, royalties, or the transfer of business "functions" such as R\&D, marketing, distribution, patents, and software, etc. Private investors enter tax havens to escape capital income taxation.

Figure 2 Personal income tax rates, 1990-2005

as percent of taxable income

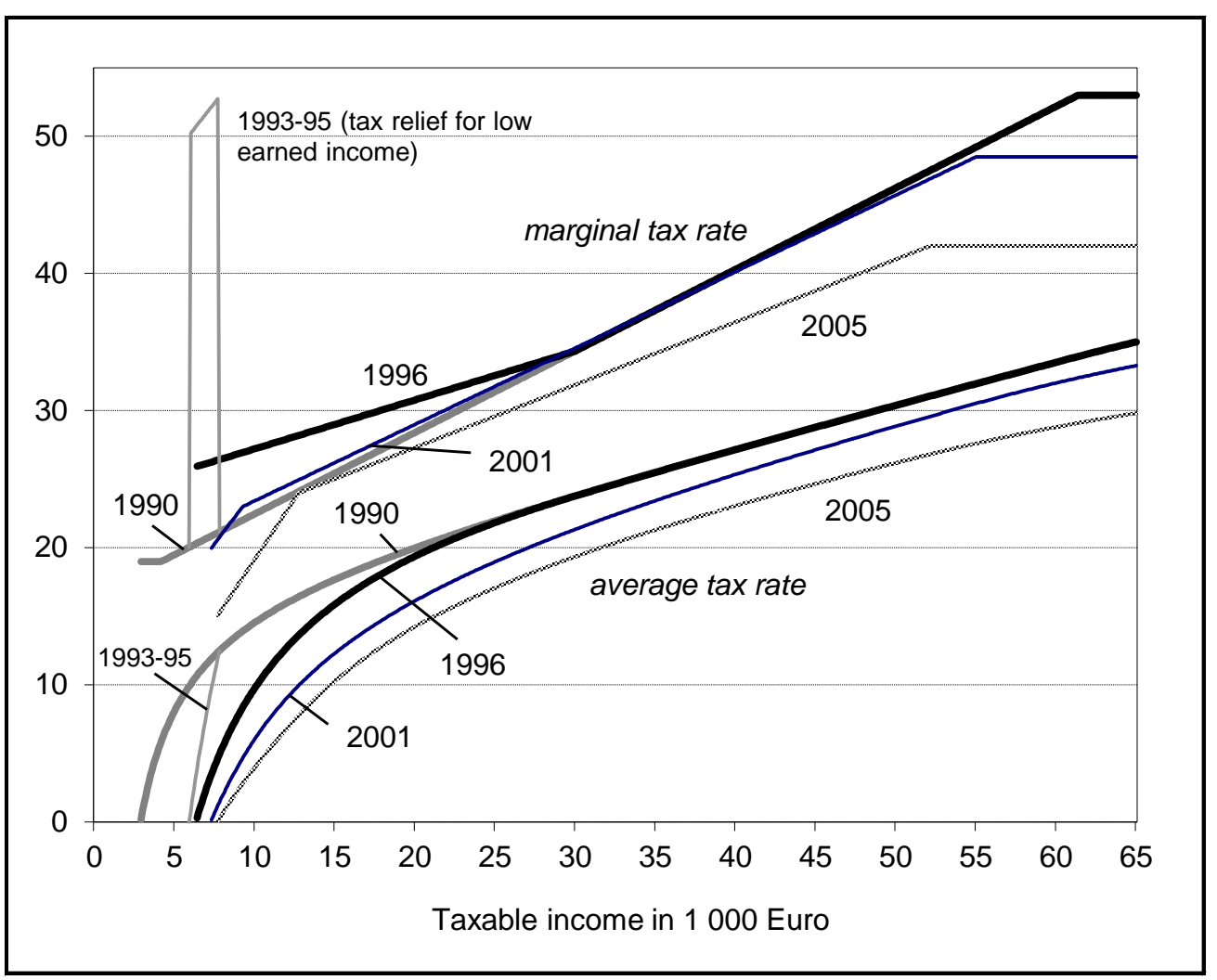

Several tax reforms over the last decades addressed these topics (see Box 1 at the end of this section). Tax rates were reduced and the tax base was broadened step-by-step, according to the "tax-cutting and base-broadening"-strategies that have been enforced in other countries since the eighties. However, it is hard to measure and evaluate the impact of those reforms given the complexity of the taxation system and the horizon of an investment over many years. 
Measures of effective tax rates try to capture the main features of the interplay between the tax base and tax rates. Widely used in economic literature and policy advice are "forwardlooking”-measures calculated according to the methodology set out by King and Fullerton (1984) and enlarged by Devereux and Griffith (1999, 2003). They analyze the impact of taxation for hypothetical investment projects or firms in the context of standard investment theory, thus taking into account cash flows arising through the life of the investment project. "Effective marginal tax rates” (EMTR) measure the proportionate difference between the cost of capital and the required post-tax real rate of return. This is relevant for existing firms considering the size of investment. "Effective average tax rates" (EATR) address discrete choices for investments and locations in which a profit above the minimum rate of return (economic rent) is expected to be earned. Therefore, for a given pre-tax net present value of an investment project or firm the impact of taxation is measured by the effect on the post-tax net present value. This measure describes the impact on the tax burden for different opportunities regarding the assets invested in (intangibles, industrial buildings, machinery, financial assets and inventories), financing sources (new equity, debt, retained earnings), and legal form, as well as for different alternatives regarding the economic background such as profitability, real interest rate and inflation.

These measures have been often utilized for the description of the business tax burden over time or across countries (European Commission, 2001, Devereux, Griffith and Klemm, 2002, Devereux et al., 2008, Elschner and Vanborren, 2009). The German Council of Economic Experts ("Sachverständigenrat") frequently resorted to these measures in assessing the German business tax burden and its reform (2001: 296, 2003: 308, 2006: 153). The EATR measure is rather relevant for the impact analysis of the business tax system on tax revenues since it is closer to standard "backward looking" measures of tax ratios, i.e., the relation of the tax revenue accrued in a single year to the respective business income, taken from company accounts or macroeconomic statistics. The latter is discussed for Germany in depth in the following Sections.

In Figure 3 we present time series of EATRs taken from Devereux, Griffith and Klemm (2002) including updates to 2005 provided by the IFS London (2005) and recent calculations for the period 2000-10 provided by the Oxford University Centre for Business Taxation (2012). The main graphs up to 2005 display the "base case" of an investment in plant and machinery, either financed by equity or retained earnings, or by debt. The simulations refer on the corporate level, i.e., without taking into account the taxation of the shareholder. The calculations until 2010 are based on an average mix of investments and financing sources. Basical- 
ly, the results show a much higher tax burden for Germany compared to the unweighted average of the 19 main Western OECD countries included. The trend of falling tax rates is rather similar to those reported for the statutory tax rates in Figure 1, although the decline in the statutory tax rate was stronger both for Germany and the OECD average. Thus, regarding the properties and assumptions of this modeling, the positive difference of the German business tax rates compared to the main OECD countries also applies to the effective average tax rates, and has rather aggravated during the nineties. It was not until after the business tax reform of 2008 Germany's business tax rates have largely closed the gap on the Western OECD average. According to the new calculations, Germany’s 2008 business tax reform reduced the EATR by 7 percentage points, thus coming down to the average of the Western OECD countries or EU 15 (see also Devereux et al., 2008, 2009, and European Commission, 2011: 133). ${ }^{2}$

Figure 3 Effective average tax rates for investments in plant and machinery financed from different sources, 1982-2010

Company/subsidiary level, excluding taxation of distributed profits at the shareholder level, including sub-central and local government business income tax rates in percent

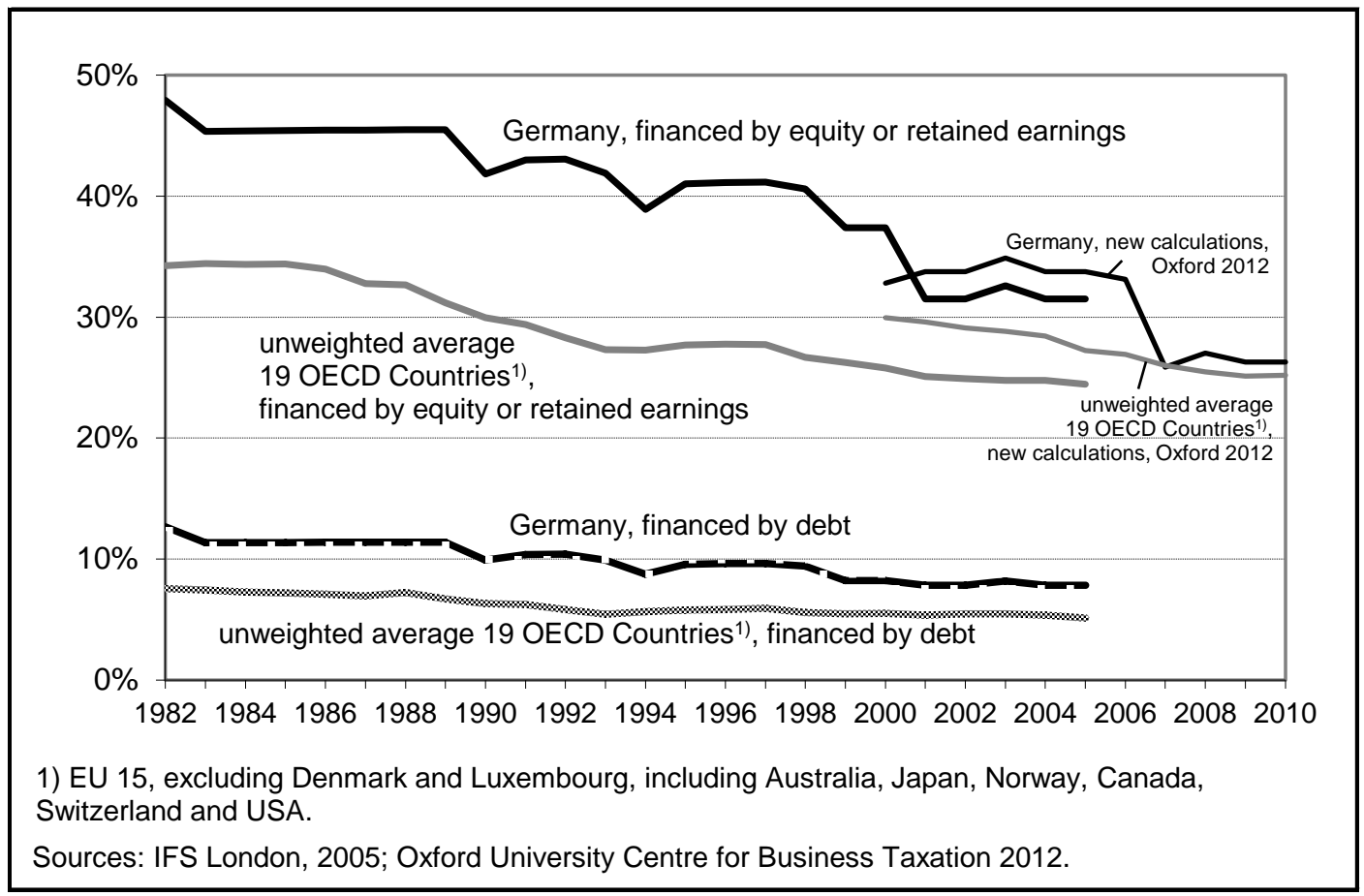

The results reported here and similar studies show remarkable differences in effective tax rates depending on the assumptions made on economic conditions and other factors that influ-

2 See also the analysis of Spengel et al. (2007) for the effects of the German business tax reform of 2008 on the average tax burden of model firms based on a broader simulation model. 
ence the tax burden. For instance, debt finance leads to much lower effective tax rates (Figure 3). This result from beneficial tax provisions such as accelerated depreciations combined with the deductibility of the interest expenditure. With respect to the assets invested in, the studies usually show higher effective tax rates for commercial property, residential buildings, and, not surprisingly, for financial assets (European Commission, 2001, Devereux, Griffith and Klemm, 2002, Devereux et al., 2008, 2009), which clearly has to do with the tax depreciation rules. With respect to higher profitability, the EATR converges to the statutory tax rate since the relative impact of tax provisions declines. A more complex picture is painted for crossborder investments when the regulations of international taxation are taken into account.

In reality, economic decisions are affected by several other tax base provisions, beyond depreciation and inventory valuation. Model-firm approaches based on financial accounting standards and tax assessments try to capture these impacts closer to reality. The "European Tax Analyzer” set out by the University of Mannheim and ZEW (Jacobs and Spengel, 1999, 2002, Spengel 2003) provides such calculations for Germany and some other main OECD countries. Likewise, the results see Germany at the top of effective tax rates in international comparison for most parameterizations in the years before 2008.

To sum up, the standard "forward-looking" modeling tools that analyze the impact of business taxation for hypothetical investment projects or firms do not give clear hints that the tax base provisions in Germany have been or are still much more generous compared to the other Western OECD countries. Insofar, the common notion provided by the pertinent literature is that Germany was a high-tax country up to the recent reform of 2008, at least for profitable investments that do not benefit from specific tax incentives.

However, with respect to current tax revenue compared to macroeconomic business income, which will be analyzed in depth for Germany in the following section, such measures of effective tax rates for hypothetical investment projects or firms should be treated with caution, in particular in the short run (Devereux, Griffith and Klemm, 2004: 373, 378, Egger et al., 2009). As these measures point out the considerable incentives and distortionary impacts of tax provisions, even conclusions on the overall location attractiveness of the business tax system are dodgy to draw. Firm-level evidence from published financial statements reveals a large variance of the underlying economic conditions as well as the complexity of the tax provisions that actually impact effective tax rates (Gorter and de Mooij, 2001, Becker and Fuest, 2004, Egger et al., 2009). It stands to reason that these incentives and distortions might significantly affect the decisions of firms and investors. 
Thus, one has to weight the results for single countries with the empirical distribution of the influencing business structure, which is unsuitable in many cases due to the lack of detailed representative firm data. Moreover, tax avoidance and tax evasion strategies, which depend on the level of tax burden, are mostly not taken into account. There is much anecdotal evidence and at least some empirical evidence that tax avoidance affects countries with high statutory business tax rates such as Germany and the USA stronger than others (see below, Section 4.3).

In contrast, the periodical tax revenue depends on the past investments and the timing of income streams, as well as the changes in tax provisions and tax rates over time. If there are many firms with low profitability, running losses, or larger stocks of losses carried forward that could be deducted from current taxable income, the link between "forward-looking" measures of effective tax rates and "backward-looking" measures of past tax revenue over corporate income might differ significantly for broader groups of firms, or even for the corporate sector as a whole.

However, in the long run "forward-looking“ and "backward-looking” measures should not diverge so much as it seems to be the case in Germany (see also the discussion by Becker and Fuest, 2006). This questions the representativeness and suitability of the "forward-looking“measures, which are widely used for the analysis of business taxation and its reform in Germany.

\section{Box 1 Significant reforms of business taxation in Germany since 1990}

1990: Corporate tax rate cut from 56 percent to 50 percent for retained profits. Significant reduction of the personal income tax rates, introduction of a linear-progressive formula schedule with a constant increase of marginal tax rates up to the top rate, which was lowered from 56 percent to 53 percent. Several personal income tax exemptions and allowances were abolished or reduced.

1991: Investment Promotion Act ("Fördergebietsgesetz") provided generous incentives for investments in East Germany for the following years, in particular high first-year allowances (up to 50 percent) and investment grants. The solidarity surcharge was introduced for the years 1991-92 with 3.75 percent on the corporate and personal income tax liability.

1993: Location Preservation Act ("Standortsicherungsgesetz") reduced the corporate income tax rate for retained profits to 45 percent, the tax rate for distributed profits to 30 percent, and the top marginal rate of personal income tax to 47 percent for income from business enterprise above about Euro 50,000. The declining-balance depreciation rate was reduced for movable fixed assets (from 30 percent to 25 percent) and for immovable fixed assets, the declining-balance depreciation for commercial buildings was replaced with a straight-line rate of 4 percent. Introduction of special depreciation allowances for SMEs. Explicit provisions against thin capitalization were introduced.

1995: Re-introduction of the solidarity surcharge with 7.5 percent on the corporate and personal income tax liability.

1997: The net wealth tax was suspended, both for individuals and for corporations, due to a sentence of the Federal Constitutional Court.

1998: Abolition of the local business tax on capital, repeal of allowances for contract loss provisions. Reduction of the solidarity surcharge rate to 5.5 percent. 
1999: Tax Relief Act ("Steuerentlastungsgesetz 1999/2000/2002") reduced the corporate income tax rate for retained profits to 40 percent and limited the top marginal personal income tax rate for income from business enterprise to 45 percent in 1999 and to 43 percent in 2000. The top marginal income tax rate was reduced to 51 percent in 2000 and to 48.5 percent in 2001 . The tax base was broadened by restrictions for provisions, for writeoffs to the lower going-concern value, for tax-neutral transfers of assets between partners and their partnerships, and by the introduction of a minimum taxation that restricted the offset of higher losses between income from different sources and from loss allocation vehicles. Several personal income tax exemptions and allowances were abolished or reduced.

2001: Tax Reduction and Business Taxation Reform Act ("Gesetz zur Senkung der Steuersätze und zur Reform der Unternehmensbesteuerung") reduced the corporate income tax rate on both retained and distributed profits to 25 percent. The then full imputation system was replaced by a tax exemption for dividends within the corporate sector, both received from domestic corporations and from abroad, and by a half-income shareholder relief for resident individuals liable to the personal income tax. Capital gains from domestic shareholdings were exempted. A personal income tax credit for the local business tax was introduced, which amounts to almost the half of the local business tax liability up to a certain cap of local rates. Further reduction of personal income tax rates, in particular of the top rate to 45 percent in 2004, and to 42 percent in 2005. Cutting back of depreciation allowances: the declining balance rate for movable fixed assets was reduced from 30 percent to 20 percent, the straightline depreciation rate for commercial buildings from 4 percent to 3 percent. The thin capitalization rules were further restricted.

2003: Introduction of stricter statutory documentation regulations for transfer pricing.

2004: Reform of the minimum taxation: repeal of the loss offset-restrictions across income types, introduction of a restriction on the use of loss carryforwards for taxable income exceeding Euro 1 million, from which only a share of 60 percent allows for loss deduction. The thin capitalization provisions were reformed and enlarged to shareholders liable to domestic taxation.

2006: Increase of the declining balance rate for movable fixed assets from 20 percent to 30 percent for investments of the years 2006 and 2007.

2007: Introduction of a second top personal income tax rate of 45 percent on taxable income exceeding Euro 250,000

2008: Business Taxation Reform Act 2008 ("Unternehmenssteuerreformgesetz 2008") reduced the corporate income tax rate from 25 percent to 15 percent and the uniform base rate ("Steuermesszahl") of the local business tax from 5 percent to 3.5 percent. For unincorporated firms liable to the personal income tax, retained profits are taxed at lower rates (around 30 percent) until they are distributed. The business tax credit to the personal income tax was enlarged. A final withholding taxation of capital income was introduced with a flat rate of 25 percent as of 2009. The tax base was broadened by the repeal of the declining-balance depreciation, by the enlargement of the local business tax base additions to all financing expenses (with a share of 25 percent and a specific allowance), by the abolition of the local business tax deduction from the corporate and personal income tax base as well as from its own tax base, by the introduction of an interest limitation ("Zinsschranke"), which refuse the deduction of interest expenses for firms with higher leverage and lower earnings before interest, taxes and depreciation (EBITDA) (not applicable to smaller firms with interest expenses below 3 million Euro or to companies that are not part of an affiliated group or to allied companies whose equity ratio of the last year was as high or even higher as the ratio of the affiliated group), by a more restricted immediate write-off of low-value assets, by stricter transfer pricing rules regarding the relocation of business "functions" to abroad, by restrictions on tax-avoiding securities lending, and by restrictions to the use of loss carryforwards in the case of a material change in the firm's ownership.

2009: The First Economic Stimulus Package ("Konjunkturpaket l") re-introduced the declining-balance depreciation for movable fixed assets at a rate of 25 percent and increased special depreciation allowances for small and medium-sized enterprises, both temporarily for investments of the years 2009-10.

\section{Tax Revenue, Macroeconomic Implicit Tax Rates, and Tax Base Erosion}

We now turn to the effective business taxation revenue in Germany and the average macroeconomic tax rates measured by the ratio of tax revenue over total corporate income. Moreo- 
ver, a comparison of the corporate income measured in national accounts with the corporate tax base reported in tax statistics gives hints to considerable tax base erosion in Germany.

\subsection{Effective Business Taxation Revenue}

Table 1 presents the entire business taxation revenue in Germany by its components for the tax statistics years from 1992 to 2008. We use published tabulations from the tax statistics (Federal Statistical Office, 2013a) in order to trace the detailed information from the tax assessment. The underlying data sets include nearly all items of the tax returns that are stored electronically by the fiscal authorities. Another main advantage of the tax statistics is that they precisely report the actual assessed tax liability accrued in the tax year. Revenue statistics, which are often used for empirical analysis and international comparisons, might considerably miss the actual tax liability for a given year. They capture current interim payments, which are based on previous tax assessments, as well as supplementary payments or repayments after the assessment for previous tax years. These timing differences compared to the assessed tax liability might heavily fluctuate with the business cycle or after major tax reforms. Disadvantages of the tax statistics are, however, that they were collected only in triennial intervals up to 2004, and that the data is rather old due to the long-lasting assessment procedures. Since 2005 yearly statistics are available. Currently (in June 2013), the recent wave of the personal and corporate tax statistics is from 2008, and for the local business tax from 2007.

The revenue from the local business tax is calculated on the basis of detailed data from the tax statistics, taking into account the distribution of local municipalities' tax rate by size groups of local population. Since there is no local business tax statistics available for 1992 and 2008, we estimate the revenue for that year from the other waves and the yearly revenue statistics. As measure of the corporate income tax revenue we use the assessed tax liability, after deduction of domestic corporate income tax (for the years until 2001/02 when Germany applied the full imputation system to avoid double taxation of distributed profits). This equals the owed corporate tax liability plus withholding taxes on capital income and investment grants, which are both credited against assessed tax liability.

For the personal income tax we estimate the portion of the tax liability falling on business income. The starting point is the assessed tax liability after deduction of child allowances from taxable income. Using detailed data form the income tax statistics of the respective years we allocate the individual tax liability according to the share of business income in total income, both positive and negative (for details of the estimation procedures see Bach and 
Buslei, 2009). The precise information of the income tax statistics allows us to confine these estimations to income from business enterprise only (i.e., less income from agriculture and forestry or from self-employed activities), to income from partnerships (i.e., less income from sole proprietors), or to dividend income received from corporations. Moreover, we estimate the withholding taxes on capital income that are not credited against domestic personal or corporate income tax, thus paid by foreigners or residents not filing a tax return. For that purpose, we compare the cash revenue from these withholding taxes with the credits for these withholding taxes reported in the personal and corporate income tax statistics for the particular years.

All in all, Germany's business income taxation including the income taxes on dividends generates revenue between 4.0 and 5.3 percent of gross domestic product (GDP) (line 26 of Table 1), or between 18 and 23 percent of total tax revenue (line 30 of Table 1). The fluctuations are influenced by the business cycle. At the same time, tax base erosion and the impact of tax reforms might have had an impact (see below, Section 3.3). In the course of the tax reform of 2001 the revenue was rather weak. For 2004, the total tax revenue amounts to Euro 89 billion or 4.0 percent of GDP. In the years after, the tax revenue increased markedly due to the macroeconomic upturn and boosting business income. Total business taxation revenue would increase to Euro 128 billion in 2007, or 5.3 percent of GDP. Due to the 2008 reform of business taxation and the beginning recession in the wake of the financial crises, tax revenue declined to 4.9 percent of GDP in 2008.

The taxes on business income (line 23 of Table 1) represent the tax burden at the firm level, as they do not include the dividend tax revenue. The taxes on income from business enterprise (line 24 of Table 1) neglect the personal income tax falling on the income from agriculture and from other self-employed activities (in particular liberal professions), which make up about 0.7 percent of GDP in 2007-08. It should be noted that these income sources are not liable to the local business tax. The taxes on income of corporations and partnerships (line 25 of Table 1) represent the taxes on "corporate income" in the narrow sense, which is analyzed in detail in the following sections. The inclusion of partnerships into the corporate sector refers to the concept of national accounts and international standards. As mentioned in Section 2, partnerships play an important role in Germany. They account for more than one third of the business tax revenue levied on the entire corporate sector. 
Table 1 Business taxation revenue ${ }^{1)}$ in Germany, 1992-2008 billion Euro

\begin{tabular}{|c|c|c|c|c|c|c|c|c|}
\hline No. & & 1992 & 1995 & 1998 & 2001 & 2004 & 2007 & 2008 \\
\hline & Local business tax & & & & & & & \\
\hline 1 & Assessed local business tax ${ }^{2)}$ & 22.5 & 20.7 & 24.5 & 23.2 & 28.4 & 42.2 & 39.9 \\
\hline 2 & Sole proprietors & 3.4 & 2.1 & 2.2 & 2.4 & 2.5 & 4.0 & 4.6 \\
\hline 3 & Partnerships & 7.9 & 6.2 & 7.0 & 7.7 & 8.7 & 13.0 & 11.5 \\
\hline \multirow[t]{2}{*}{4} & Corporations & 11.3 & 12.3 & 15.3 & 13.0 & 17.3 & 25.2 & 23.8 \\
\hline & \multicolumn{8}{|l|}{ Corporate income tax } \\
\hline 5 & Owed corporate income tax liability ${ }^{3)}$ & 16.3 & 13.5 & 18.7 & 8.8 & 16.5 & 21.0 & 12.3 \\
\hline 6 & Withholding taxes on capital credited ${ }^{4)}$ & 2.0 & 4.4 & 7.7 & 8.2 & 6.3 & 10.6 & 11.4 \\
\hline 7 & Gross revenue & 18.3 & 17.9 & 26.4 & 16.9 & 22.8 & 31.6 & 23.7 \\
\hline 8 & Solidarity surcharge on gross revenue & 0.7 & 1.3 & 1.5 & 0.9 & 1.3 & 1.7 & 1.3 \\
\hline \multirow{3}{*}{$\begin{array}{r}9 \\
10\end{array}$} & \multicolumn{8}{|l|}{ Personal income tax } \\
\hline & Assessed personal income tax liability ${ }^{5)}$ & 136.9 & 142.3 & 165.1 & 170.6 & 180.8 & 211.0 & 220.0 \\
\hline & $\begin{array}{l}\text { Assessed personal income tax liability } \\
\text { after deduction of child allowances }{ }^{6)} \\
\text { thereof }{ }^{7)}\end{array}$ & 136.9 & 142.3 & 152.1 & 153.0 & 163.5 & 192.9 & 202.6 \\
\hline 11 & on total business income & 31.7 & 28.9 & 36.5 & 30.3 & 30.0 & 41.7 & 43.8 \\
\hline 12 & on income from business enterprise & 21.1 & 17.9 & 23.2 & 16.1 & 15.8 & 24.5 & 25.7 \\
\hline 13 & on partnerships' business income & 11.0 & 11.7 & 15.8 & 11.1 & 11.5 & 18.0 & 18.9 \\
\hline 14 & on dividend income & -1.3 & -1.6 & -0.9 & -0.9 & 1.0 & 2.3 & 2.4 \\
\hline 15 & $\begin{array}{l}\text { Assessed solidarity surcharge } \\
\text { thereof }^{7)}\end{array}$ & 5.3 & 9.9 & 8.2 & 8.3 & 8.6 & 10.3 & 10.8 \\
\hline 16 & on total business income & 1.2 & 2.0 & 1.8 & 1.5 & 1.4 & 2.0 & 2.1 \\
\hline 17 & on income from business enterprise & 0.8 & 1.2 & 1.2 & 0.8 & 0.8 & 1.2 & 1.3 \\
\hline 18 & on business income of partnerships & 0.4 & 0.8 & 0.8 & 0.5 & 0.5 & 0.9 & 0.9 \\
\hline 19 & on dividend income & 0.0 & -0.1 & 0.0 & 0.0 & 0.0 & 0.1 & 0.1 \\
\hline & \multicolumn{8}{|l|}{ Withholding taxes on capital not credited } \\
\hline 20 & Withholding taxes on capital not credited & 1.8 & 3.8 & 4.0 & 11.8 & 3.6 & 6.4 & 7.7 \\
\hline 21 & Solidarity surcharge & 0.1 & 0.3 & 0.2 & 0.6 & 0.2 & 0.4 & 0.4 \\
\hline \multirow[b]{2}{*}{22} & \\
\hline & $\begin{array}{l}\text { Taxes on business and dividend income } \\
(1+7+8+11+14+16+19+20+21) \\
\text { thereof }\end{array}$ & 75.0 & 73.3 & 94.0 & 84.4 & 88.8 & 128.4 & 121.5 \\
\hline \multirow{4}{*}{$\begin{array}{l}23 \\
24 \\
25\end{array}$} & $\begin{array}{l}\text { Taxes on business income } \\
(1+7+8+11+16)\end{array}$ & 74.4 & 70.8 & 90.7 & 72.8 & 84.0 & 119.2 & 110.9 \\
\hline & $\begin{array}{l}\text { Taxes on income from business enterprise } \\
(1+7+8+12+17)\end{array}$ & 63.4 & 59.1 & 76.8 & 58.0 & 69.0 & 101.2 & 92.0 \\
\hline & Taxes on income of corporations and & & & & & & & \\
\hline & partnerships $(3+4+7+8+13+18)$ & 49.6 & 50.3 & 66.8 & 50.3 & 62.0 & 90.3 & 80.1 \\
\hline & \multicolumn{8}{|l|}{$\begin{array}{l}\text { Business taxation revenue as percent of } \\
\text { gross domestic product (GDP) }\end{array}$} \\
\hline 26 & $\begin{array}{l}\text { Taxes on business and dividend income } \\
\text { thereof }\end{array}$ & 4.6 & 4.0 & 4.8 & 4.0 & 4.0 & 5.3 & 4.9 \\
\hline 27 & Taxes on business income & 4.5 & 3.8 & 4.6 & 3.5 & 3.8 & 4.9 & 4.5 \\
\hline \multirow{3}{*}{$\begin{array}{l}28 \\
29\end{array}$} & Taxes on income from business enterprise & 3.8 & 3.2 & 3.9 & 2.8 & 3.1 & 4.2 & 3.7 \\
\hline & $\begin{array}{l}\text { Taxes on income of corporations and } \\
\text { partnerships }\end{array}$ & 3.0 & 2.7 & 3.4 & 2.4 & 2.8 & 3.7 & 3.2 \\
\hline & \multicolumn{8}{|l|}{$\begin{array}{l}\text { Business taxation revenue as percent of } \\
\text { total tax revenue }\end{array}$} \\
\hline 30 & $\begin{array}{l}\text { Taxes on business and dividend income } \\
\text { thereof }\end{array}$ & 20.4 & 18.1 & 21.7 & 18.4 & 19.1 & 23.0 & 21.2 \\
\hline \multirow{3}{*}{$\begin{array}{l}31 \\
32 \\
33\end{array}$} & Taxes on business income & 20.2 & 17.5 & 20.9 & 15.8 & 18.1 & 21.4 & 19.4 \\
\hline & Taxes on income from business enterprise & 17.2 & 14.6 & 17.7 & 12.6 & 14.9 & 18.1 & 16.1 \\
\hline & $\begin{array}{l}\text { Taxes on income of corporations and } \\
\text { partnerships }\end{array}$ & 13.5 & 12.4 & 15.4 & 10.9 & 13.4 & 16.2 & 14.0 \\
\hline & lomestic & . & 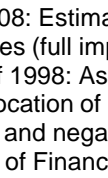 & $T_{1}$ & 1. & diting & ding & $\begin{array}{l}\text { on } \\
\text { ing tax } \\
\text { unts. }\end{array}$ \\
\hline
\end{tabular}


The analysis also demonstrates the high importance of local business taxation, which raises more than 40 percent of the business tax revenue from corporations including partnerships, and well over one third of the tax revenue from total business income in 2007-08. Moreover, the personal income tax share of the entire business tax revenue is remarkable in Germany. Beside partnerships it also includes the sole proprietors' taxes. The revenue share of the corporate income tax is rather low in Germany, which is also demonstrated by the following international comparison.

International comparisons of macroeconomic tax ratios mostly rely on the OECD revenue statistics (OECD, 2012). Table 2 highlights the tax revenue from corporate income over GDP for the main OECD countries. The OECD revenue statistics relies on the national revenue statistics and might therefore be flawed by distortions mentioned above regarding the timing of the revenue. Moreover, in the case of Germany these statistics are particularly misleading since they only include the revenue falling on incorporated firms, given the remarkable tax share of unincorporated partnerships, although the numbers for the other countries might be also somewhat distorted by this effect. Indeed, Germany's tax-to-GDP ratio is rather low compared to the OECD and EU 15 average, and the other main OECD countries listed in the table. As demonstrated above, one should at least include the partnerships' share into the revenue of corporate business taxation. If we therefore refer to the business tax revenue on income of corporations and partnerships over GDP (line 29 of Table 1), Germany's tax-to-GDP ratio turns out to be much higher. However, even relying on these numbers the tax revenue was rather low in 2001. During the last years up to 2007 the German tax revenue was catching up to the international average, although the other countries also increased their revenue, presumably due to the boosting economy up to 2007.

Moreover, the international comparison indicates that in other countries the tax revenue from corporate income significantly rose since 1992, although the tax rates in many countries have been lowered markedly (see above, Section 2). This “corporate income tax rate-revenue paradox" might have something to do with changes in the size and profitability of the corporate sector, but might also reflect some broadening of the tax base, thus utilizing a larger part of corporate income for taxation (see Piotrowska and Vanborren, 2008). 
Table 2 Tax revenue from corporate income in international comparison, 1992-2008 as percent of gross domestic product (GDP) $)^{1)}$

\begin{tabular}{|c|c|c|c|c|c|c|c|}
\hline & 1992 & 1995 & 1998 & 2001 & 2004 & 2007 & 2008 \\
\hline \multicolumn{8}{|l|}{$\begin{array}{l}\text { Tax revenue from corporate income, } \\
\text { OECD revenue statistics }\end{array}$} \\
\hline OECD total & 2.4 & 2.8 & 3.0 & 3.2 & 3.3 & 3.8 & 3.5 \\
\hline EU 15 & 2.2 & 2.6 & 3.3 & 3.4 & 3.1 & 3.5 & 3.2 \\
\hline France & 2.0 & 2.1 & 2.6 & 3.4 & 2.8 & 3.0 & 2.9 \\
\hline Italy & 4.2 & 3.5 & 2.9 & 3.5 & 2.8 & 3.8 & 3.7 \\
\hline Sweden & 1.4 & 2.8 & 2.7 & 2.9 & 3.0 & 3.7 & 3.0 \\
\hline Netherlands & 2.9 & 3.1 & 4.2 & 3.9 & 3.1 & 3.2 & 3.2 \\
\hline United Kingdom & 2.1 & 2.8 & 3.9 & 3.4 & 2.8 & 3.4 & 3.6 \\
\hline USA & 2.3 & 2.9 & 2.7 & 1.9 & 2.5 & 3.0 & 2.0 \\
\hline Canada & 1.8 & 2.9 & 3.6 & 3.1 & 3.6 & 3.5 & 3.4 \\
\hline Japan & 4.9 & 4.3 & 3.7 & 3.5 & 3.7 & 4.8 & 3.9 \\
\hline Germany & 1.5 & 1.0 & 1.6 & 0.6 & 1.6 & 2.2 & 1.9 \\
\hline \multicolumn{8}{|l|}{ For comparison: } \\
\hline $\begin{array}{l}\text { Germany, assessed tax revenue incl. local } \\
\text { business and income tax share of partnerships }{ }^{2)}\end{array}$ & 3.0 & 2.7 & 3.4 & 2.4 & 2.8 & 3.7 & 3.2 \\
\hline
\end{tabular}

\subsection{Macroeconomic Corporate Income and Implicit Tax Rates}

Instead of gross national product (GDP) one should use an adequate aggregate of corporate income as denominator for calculating macroeconomic implicit tax rates on corporate business income. Based on a similar concept of the European Commission (2013: 289), we derive a yearly corporate income from the income accounts of the national accounts statistics (see Figure 4 and Table 3). The idea is to approximate the actual taxable income as close as possible. Starting point is the net entrepreneurial income as measured in German national accounts (ESA 95 Code: B.4n) for the corporate sector (S.11 and S.12). This income is derived from the net operating surplus (ESA 95 Code: B.2n), which represents the earnings before interest and taxes (EBIT) from ordinary business operations, plus received property income, minus paid property income (ESA 95 Code: D.4rec/pay) ${ }^{3}$. As dataset we use the current revision of German national accounts of February 2013 (Federal Statistical Office 2013b).

3 The property income of the national accounts includes interest and dividend income, reinvested earnings on direct foreign investment, rents on land, and property income attributed to insurance policy holders. 
Figure 4 Distribution of gross national income (GNI), 1991-2012 structure in percent

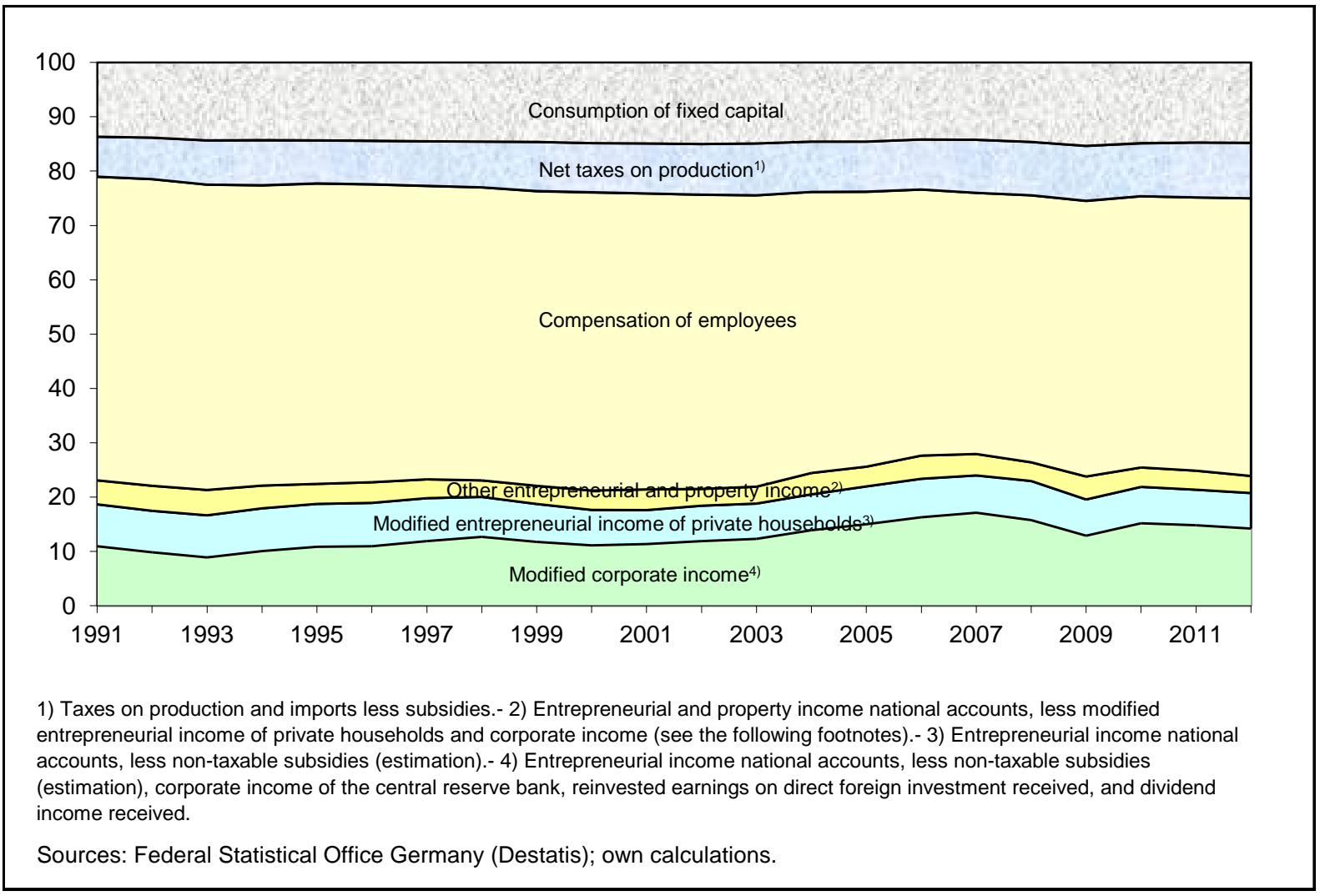

We modify this approach with respect to the following items (see the adjustment items in Table 3). First, we deduct the reinvested earnings on direct foreign investment received by resident firms (ESA 95 Code: D.43rec) since in almost all cases these incomes are not liable to domestic taxation. Second, we subtract the dividend income received (ESA 95 Code: D.42rec) in order to avoid double counting of these income at the paying and the receiving firm. Third, we reduce capital and business income by the non-taxable subsidies, which we roughly estimate by 20 percent of the category "production subsidies other than on products" (ESA 95 Code: D.39rec) (Bach und Dwenger, 2007: 62), and the corporate income of the central reserve bank. ${ }^{4}$

4 In previous issues of the German national accounts up to 2011, the local business tax ("Gewerbesteuer") was factored into the position "other taxes on production" in the generation of income account (ESA 95 Code: D.29), like taxes on property, other fixed assets, or payroll taxes. These taxes are deducted from the net operating surplus. This assignment reflected the tradition of local business taxation in Germany, which was formerly levied on a broader base of the firm's value added and equity. Since the local business tax base is nowadays largely levied on business income (see above, Section 2), German statistical authorities reconsidered this assignment as of 2012. The local business tax revenue is now booked into the category "taxes on income” of the secondary distribution of income account (ESA 95 Code: D.51), which does not affect the net operating surplus and the primary income. 
Figure 4 highlights the performance of the resulting modified corporate income in the context of the distribution of gross national income (GNI) (for a similar approach see Piotrowska and Vanborren, 2008, and Sørensen, 2007). Note that the GNI, formerly known as gross national product (GNP), differs little from the gross domestic product (GDP) by the external balance of primary incomes. ${ }^{5}$ We likewise modify the entrepreneurial income of households in adjusting for non-taxable subsidies and calculate the other entrepreneurial and property income as difference to the total entrepreneurial and property income aggregate. The other income components are directly taken from the allocation of primary income account of national accounts.

Table 3 Tax revenue, corporate income, and implicit tax rates of corporations incl. partnerships, 19922008

\begin{tabular}{|c|c|c|c|c|c|c|c|}
\hline & 1992 & 1995 & 1998 & 2001 & 2004 & 2007 & 2008 \\
\hline & \multicolumn{7}{|c|}{ billion Euro } \\
\hline Taxes on corporate income ${ }^{1)}$ & 49.6 & 50.3 & 66.8 & 50.3 & 62.0 & 90.3 & 80.1 \\
\hline \multicolumn{8}{|l|}{ Reference income corporations, national accounts } \\
\hline Entrepreneurial income, corporations & 200.1 & 239.6 & 305.2 & 329.1 & 407.4 & 567.6 & 500.2 \\
\hline - reinvested earnings on foreign investm. received & -1.1 & 0.8 & 1.9 & -19.8 & 18.8 & 30.9 & -21.0 \\
\hline - dividend income from residents (estimation) & 18.9 & 17.7 & 29.6 & 65.4 & 39.6 & 49.4 & 54.5 \\
\hline Corporate income, European Commission & 182.4 & 221.1 & 273.7 & 283.4 & 349.0 & 487.3 & 466.7 \\
\hline - other dividend income received & 8.1 & 11.5 & 17.1 & 36.6 & 36.8 & 55.6 & 63.4 \\
\hline $\begin{array}{l}\text { - non-taxable subsidies (estimated), corporate } \\
\text { income of the central reserve bank }\end{array}$ & 114 & & 107 & 106 & 42 & 8.5 & 8.7 \\
\hline Modified cornorate income & 1629 & 1991 & 2459 & 2362 & 3080 & 1232 & 3946 \\
\hline 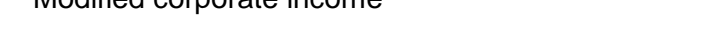 & $10<.5$ & 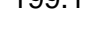 & $\angle 40.9$ & $\angle 00 . \angle$ & 500.0 & $4 \angle 0.2$ & 094.0 \\
\hline Implicit tax rates & \multicolumn{7}{|c|}{ percent } \\
\hline based on corporate income, European Commission & 27.2 & 22.7 & 24.4 & 17.7 & 17.8 & 18.5 & 17.2 \\
\hline based on modified corporate income & 30.4 & 25.3 & 27.2 & 21.3 & 20.1 & 21.3 & 20.3 \\
\hline For comparison: statutory tax rates ${ }^{2)}$ & 47.1 & 43.1 & 42.8 & 38.3 & 38.3 & 38.3 & 29.8 \\
\hline \multicolumn{8}{|c|}{$\begin{array}{l}\text { 1) Results from the tax statistics of the respective year. Local business tax, corporate income tax, personal income tax share on } \\
\text { partnership income, solidarity surcharge.- 2) Of incorporated firms: corporate income tax (until } 2001 \text { on distributed profits), } \\
\text { solidarity surcharge, local business tax, excluding taxation of distributed profits at the shareholder level. }\end{array}$} \\
\hline Office Germar & & & & & & & \\
\hline
\end{tabular}

As a result, the share of our modified corporate income in GNI increased by almost 6 percentage points from 1992 to 2008, from 9.9 to 15.8 percent, whereas the share of the other entrepreneurial and property income components slightly decreased over that period (Figure 4). This striking trend in “corporatization” can also be observed for many other European countries (Piotrowska and Vanborren, 2008). The reasons behind these trends might be an increas-

5 Balance of primary incomes receivable from the rest of the world less primary incomes payable to nonresident units. Since 2005, this balance makes up around +2 percent of GDP. At the end of the nineties, it was around -1 percent of GDP. 
ing profitability of the corporate sector, an increasing share of economic activity performed under corporate legal forms, or income shifting from personal to corporate income tax. The share of total entrepreneurial and property income in GNI increased by 4.3 percentage points in Germany from 1992 to 2008, while the compensation of employees falls by 7.3 percentage points in that period. The taxes on production and imports less subsidies rose by 2.2 percentage points due to the increase in indirect taxation (VAT, energy taxes) and the modest retrenchment in subsidies. The share of the consumption of fixed capital (i.e., the depreciation aggregate) increased only slightly. Thus, with respect to net national income at factor cost, i.e., the sum of the compensation of employees and total entrepreneurial and property income, there was a considerable redistribution of factor income in favor of corporate income and at the expense of labor income in Germany, notably since 2001. This trend was halted with the strong recession in 2008-09, as indicated by Figure 4. However, with the fast recovery of the German economy, corporate income and other entrepreneurial and property incomes partly caught up to their shares before the crises.

Calculated in absolute terms, the modified corporate income rose by 140 percent from 1992 to 2008, while GNI only increased by 50 percent and the compensation of employees only by 32 percent. In the same period, the taxes on corporate income, i.e., on the income of corporations and partnerships (see line 25 of Table 1), rose by merely 62 percent. This means that the average tax burden in relation to corporate income decreased markedly over that period.

In Table 3 we present implicit tax rates on corporate income calculated according to the concept of the European Commission (2013: 289). Accordingly, we divide the taxes on corporate income (taken from line 25 of Table 1, including the business tax share of the partnerships) by the modified corporate income aggregates derived in Table 3. Beside our modified corporate income concept described above, we also take into account the European Commission's income concept, which neglects some further adjustments of our approach, i.e., the comprehensive correction of dividend income for double counting and the correction for the estimated non-taxable subsidies (see above, p. 18). This allows to better compare the implicit tax rates on corporate income with those for other countries reported in European Commission (2013: 257). The implicit tax rates on corporate income reported there do not include figures for Germany since the revenue statistics used in this study do not allow an apportionment of the local business tax revenue and the personal income tax revenue by partnerships and other taxpayers (see above, and Bach and Buslei, 2009). Due to the comprehensive utilization of tax statistics we present here, for the first time for Germany, macroeconomic implicit tax rates on corporate income. 
Figure 5 Statutory tax rates, effective average tax rates (EATR) and implicit tax rates (ITR) on corporate income in Germany, 1991-2010

including sub-central and local government business income tax rates

in percent

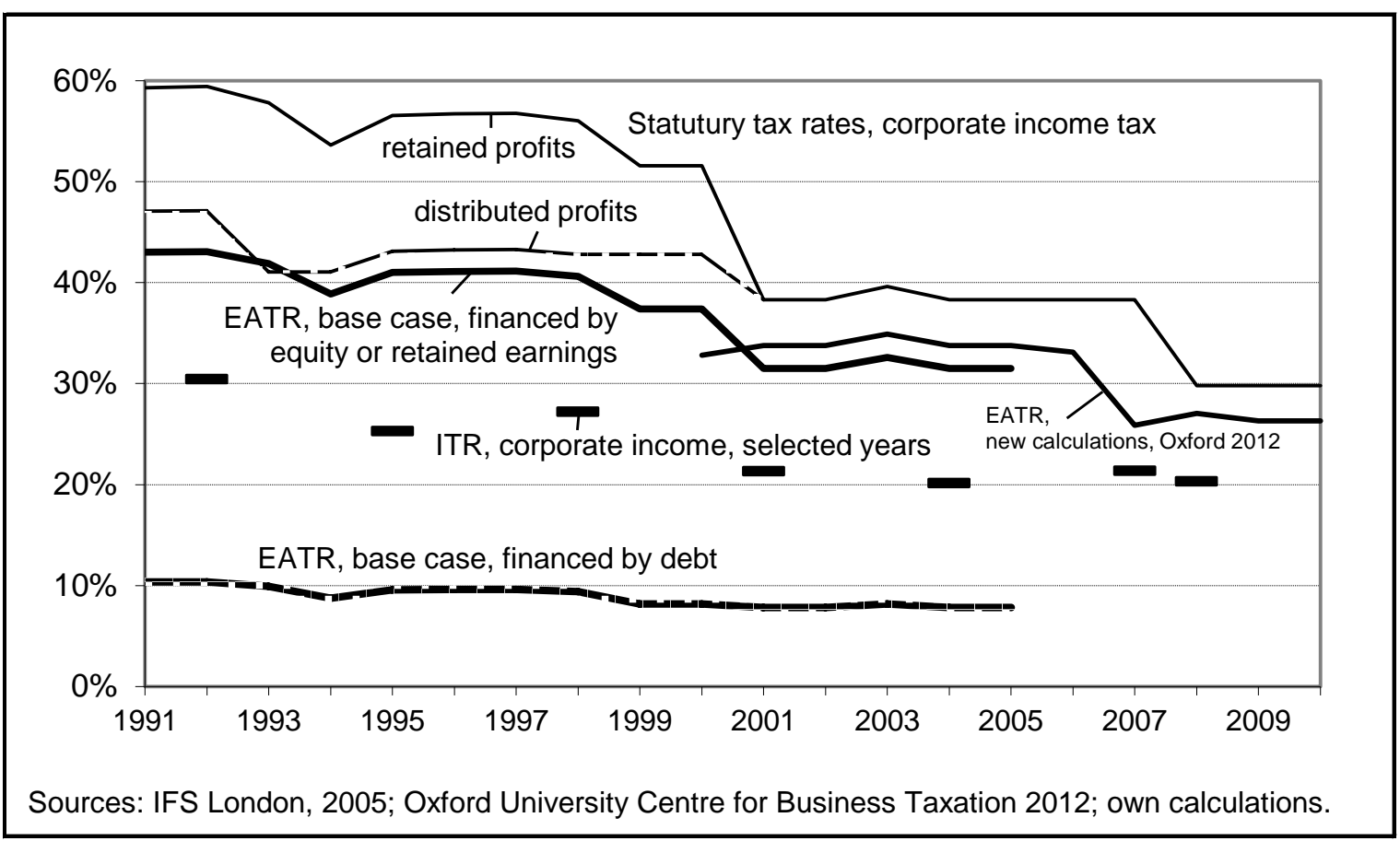

Figure 5 puts the resulting implicit tax rates (ITR) into the context of the statutory tax rates as well as the effective average tax rates (EATR) calculated according "forward-looking" simulation models (see Figure 1 and Figure 3 in Section 2). The results show that implicit tax rates are falling considerably short of the statutory tax rates, and also of the simulated effective tax rates. Since our proposed modified corporate income is lower than the Commission's corporate income for all years, the implicit tax rates based on our concept are somewhat higher, but the differences do not count much with respect to the trend. There is a clear trend in declining implicit tax rates since the beginning of the nineties, although the tax rates remained rather high in Germany up to 1998. This reflects the rising tax base erosion compared to the macroeconomic corporate income that could be observed in that years (see below, Section 3.3). In the years after 1998, the substantial tax rate cuts have further impaired the implicit tax rates similar to the EATRs. Since 2004, the implicit tax rates increase moderately, as the tax revenue increases somewhat stronger than corporate income. For 2008 there is a reduction due to the tax reform and the beginning recession. All in all, our estimations suggest that the average implicit tax rate on German corporate income was around 25 to 30 percent in the 90ies and around 21 percent since 2001. 


\subsection{Corporate Tax Base Erosion}

The trends in implicit tax rates presented in the previous Section 3.2 give hints to considerable tax base erosion in Germany, i.e., taxable income falling short of economic income. In this section we compare the corporate tax base reported in the tax statistics with the corporate income measured in national accounts.

As a starting point for the comparison we use our modified corporate income derived from national accounts data. We further modify this concept by the following items taking from the national accounts data in order to be in line as close as possible with the adjusted gross income concept of taxation (see also the complete calculation scheme in the upper panel of Table 4, starting from the entrepreneurial income of national accounts). First, we do not generally deduct received dividends from the reference income of corporations (line 6). For the years up to 2001 we do not deduct dividend income since this corresponds to the full imputation scheme, which was applied until 2001, when received dividends increased taxable income, and double taxation was ruled out by crediting the corporate income tax. For the following years the reference income of corporations is reduced by 95 percent of the dividends received by non-financial corporations. The remaining 5 percent reflect the adjustment for business expenses based on tax-free dividend income (see Sec. 8b German Corporate Income Tax Code). In the case of financial corporations we reduce the reference income by an estimated 30 percent of the dividends received, which roughly accounts for the only partial exemption of dividend income received by the financial sector (see the special regulation of Sec. 8b sub. 7 and 8 German Corporate Income Tax Code). ${ }^{6}$ Second, the local business tax revenue is subtracted from the reference income since the local business tax liability was deductible from taxable income until 2007. The other adjustments made for the modified corporate income described in the previous Section 3.2 (see Table 3) still apply, as regards reinvested earnings on foreign investments, estimated non-taxable subsidies, and corporate income of the central reserve bank.

6 The banking statistics of the Deutsche Bundesbank provides current information on the shareholdings, both in portfolio investments and in shares in affiliated enterprises, http://www.bundesbank.de/statistik/statistik_banken_tabellen.en.php 
Table 4 Business income of corporations incl. partnerships in national accounts and tax statistics, 1992-2008

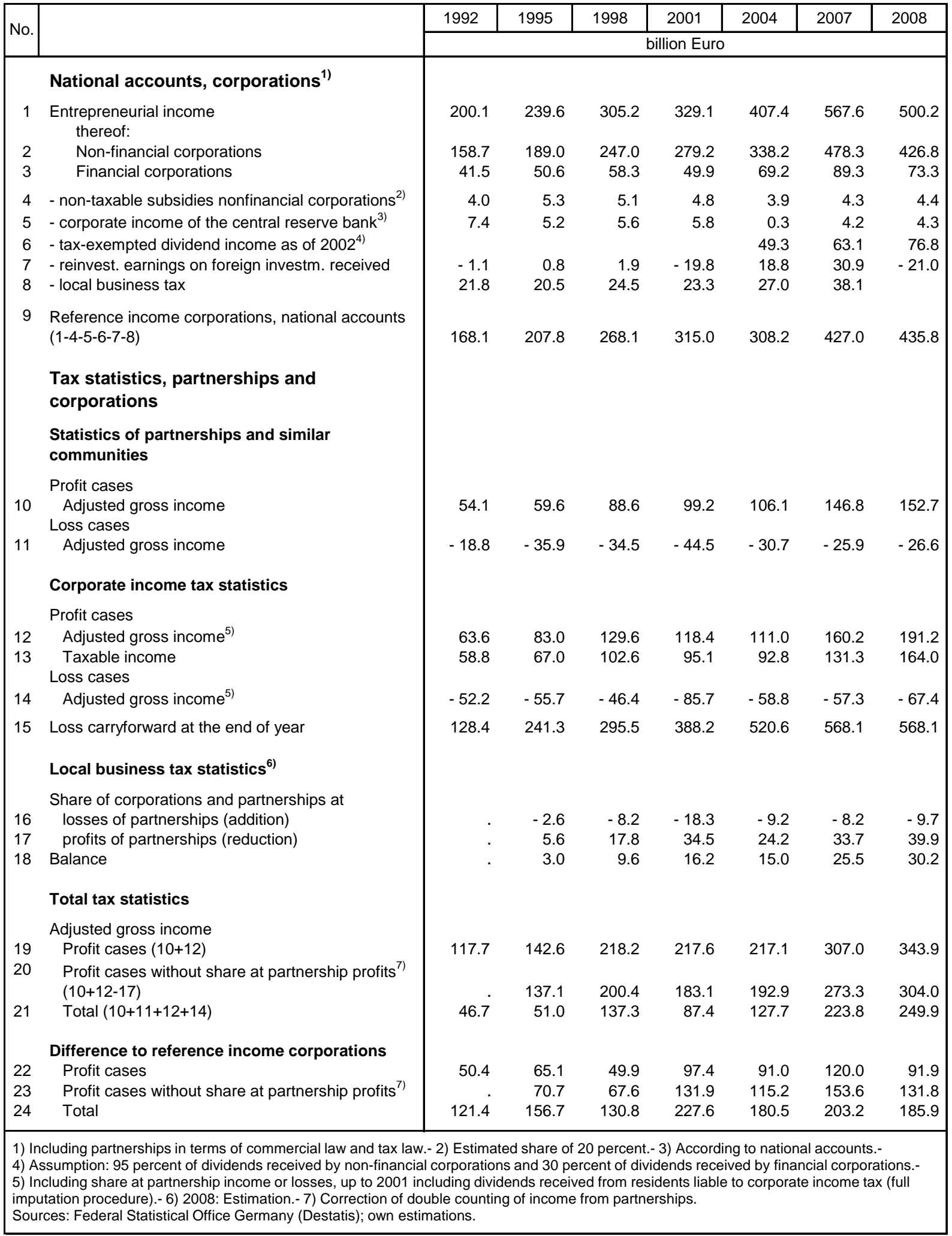

Due to the full addition of dividend income up to 2001 the resulting reference income of corporations (line 9 of Table 4) is much higher for that years compared with the modified corporate income used for the calculation of the implicit tax rates above (see Table 3). For the years 
until 2007, the only partly addition of dividend income and the deduction of the local business tax largely cancel each other out. In 2008, the repeal of the local business tax deduction reincreases the difference.

The corporate tax base is measured by the adjusted gross income ("Gesamtbetrag der Einkünfte”) reported in the respective tax statistics. This income comprises the sum of taxable income from different sources such as income from business enterprise, agriculture, selfemployed activities etc, after deduction of operating expenses, other income-related expenses, income-specific allowances, and deductible donations or contributions. If the taxpayer is parent of a tax group, the assigned income of the subsidiaries is included in adjusted gross income. The corporate income tax statistics also report the taxable income after deduction of losses carried forward from previous tax years or carried back from following tax years, on which the tax rate is applied. Moreover, the statistics discloses the stock of tax loss carryforwards at the end of year. The statistics of partnerships, however, does not provide such information from the assessment since the taxable income is passed to the shareholders who have to enter it into their tax return. Due to this "transparent" taxation of partnerships we should adjust the aggregate corporate income collected from the tax statistics for profit and loss transfers of partnerships to other affiliated corporations including affiliated partnerships, in order to avoid double counting of income. We take this information from the local business tax statistics. $^{7}$

The results for the adjusted gross income reported in the tax statistics indicate a considerable erosion of the tax base, compared with the corporate income derived from national accounts (Table 4, Figure 6). What is astonishing is the high weight of running tax losses in the observed tax years. The ratio of losses over income was very high in 1995 and 2001, but also in the other years it was rather high (see also the detailed analysis below, section 4.1). For instance, for 2004 the ratio was 53 percent for the corporate income tax, and 29 percent for the partnerships. For 2007-08, the respective ratios declined to 35 percent and 17 percent. The difference between adjusted gross income and taxable income reported in the corporate in-

7 With respect to the statistics of partnerships it should be noted that they include not only medium-sized businesses and even some bigger firms, which often use unincorporated legal forms. The statistics of partnerships also includes other companionships such as unincorporated consortia, communities of heirs, joint ownerships of real estate, or other and civil law associations not liable to corporate income tax. Such institutions and organizations are mostly assigned to the household sector in national accounts. However, as they should not involve higher income aggregates, we should not overestimate corporate income so much in tax statistics. 
come statistics demonstrate the impact of intertemporal loss offset. The considerable amount of running losses increased the stock of tax loss carryforwards in high gear. From 1992 to 2008, the latter increased by more than 340 percent. In 2008, the tax loss carryforwards amounted to Euro 568 billion, which equates to 23 percent of GDP or 3 times the positive adjusted gross income of that year. For partnerships, the income tax statistics provide no direct information on the stocks of tax loss carryforwards due to the "transparent" taxation. As far as partnerships’ running tax losses are passed to shareholders liable to the personal income tax, the shareholders often would have offset these losses against positive income from other sources (see Bach and Buslei, 2009). Actually, loss allocation vehicles mostly use partnership legal forms in Germany. For partnerships liable to the local business tax (farmers and liberal professionals are exempted), the amount of local business tax loss carryforwards amounted to Euro 136 billion in 2007, which equates to 1.45 times the positive taxable gross income of that tax (“Gewerbeertrag”) in that year. Notably, the German tax legislation restricted the use of loss carryforwards as of 2004, both in income tax and local business tax.

Figure 6 Business income of corporations incl. partnerships in national accounts and tax statistics, 1992- 2008 billion Euro

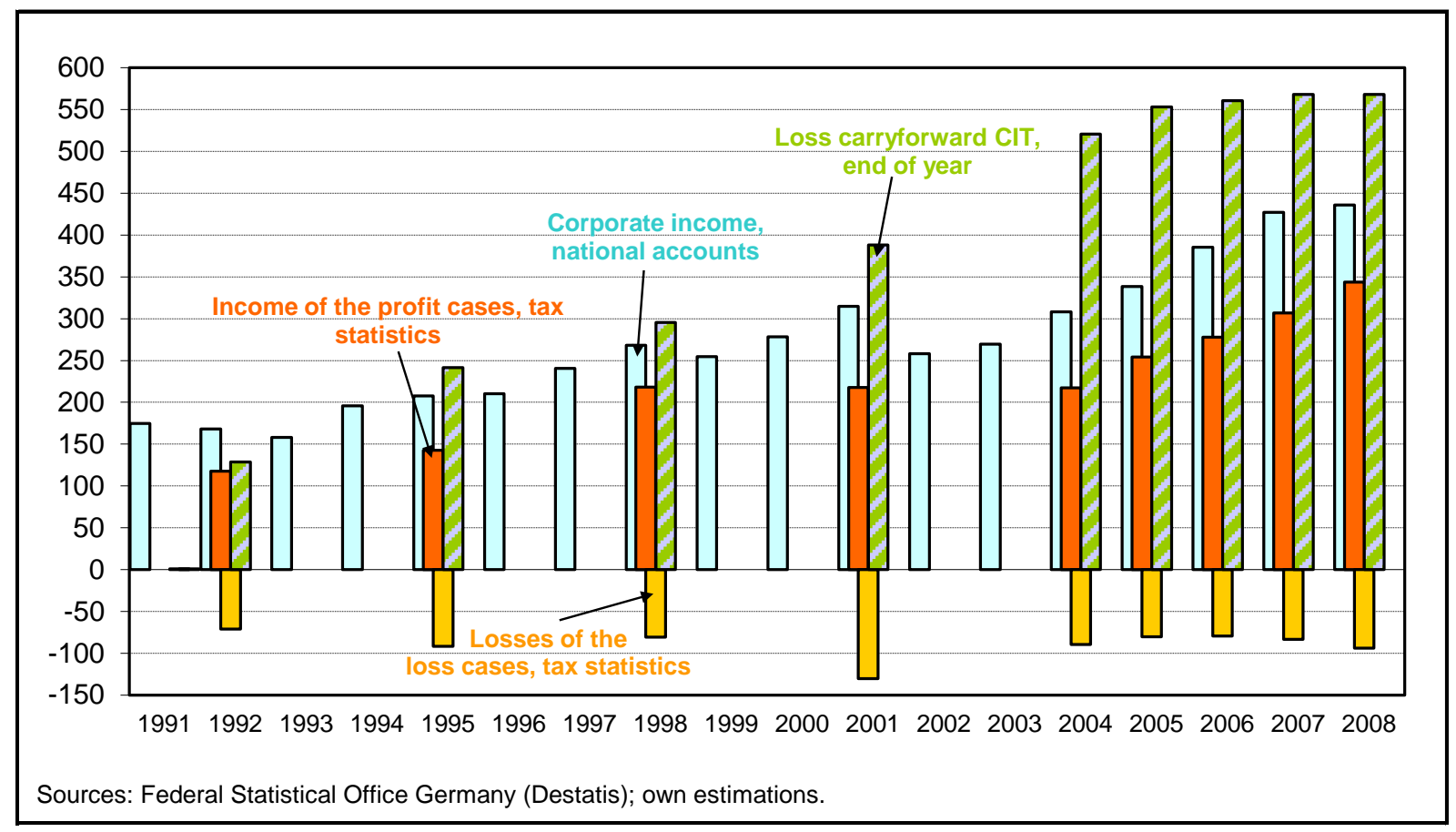

Altogether, our calculations reveal a considerable gap between corporate income derived from national accounts and taxable gross income reported in the tax statistics. Even if we refer to the positive adjusted gross income only, the difference adds up to Euro 91 billion in 2004 (line 22 of Table 4), which equates to more than 4 percent of GDP in that year. Since the tax 
losses of the loss cases should be incorporated in the macroeconomic figures from national accounts as well, we actually should refer to the difference based on the balanced income aggregate of profit and loss cases (line 24 of Table 4), which leads to a gap of Euro 180 billion in 2004. Even this number is not adjusted by the double counting of profit and loss transfers between partnerships and other affiliated corporations, which makes up another Euro 15 billion on balance (line 18 of Table 4). The gap has increased over the years up to 2007. For 2008, there is a marked decline due to the broadening of the tax base involved by the 2008 reform of business taxation back to the levels of 2004. However, in relation to GDP or corporate income, the gap is somewhat lower than in 2004.

\subsection{How Reliable Are the Entrepreneurial Income Aggregates of German National Accounts?}

Before further analyzing the considerable gap between corporate income measured in national accounts and in tax statistics as an indicator for tax base erosion, one should scrutinize how reliable are the corporate income aggregates of national accounts effectively. This raises questions with respect to conceptual differences in the income definition and determination rules. Another issue regards the impact of insufficient data sources for an independent bottom-up calculation of the entrepreneurial income for the total economy, which is especially a problem for Germany.

Conceptual differences in the income definition and determination rules between national accounts and financial or tax accounting are often discussed in the literature (Luh, 1996, Görzig and Schmidt-Faber, 2001, Heckemeyer and Spengel, 2008, European Commission, 2013: 293, Federal Statistical Office, 2009: 176). The main issues of this debate are picked out in the following. Basically, the goal of creditor protection (lowest value principle, recognition-of-loss principle) traditionally plays an important role in German financial and tax accounting. With respect to the valuation of assets and liabilities the lowest value principle and the recognition-of-loss principle apply, which systematically lead to hidden reserves in the firms' balance sheets. In contrast, the income concept of national accounts aims to capture the economic income generated and accrued in a certain period. For this reason, consumption of fixed capital is not calculated at acquisition prices as it is mandatory in financial accounts, but at replacement costs of the current period. In times of inflation this would lead to higher depreciation valuations in national accounts. On the other hand, accelerated depreciation schemes or special depreciation allowances for SMEs are neglected in national accounts, which generally apply straight-line depreciation. Furthermore, the national accounts usually 
consider a longer economic service life of fixed assets. These effects might largely offset the higher valuation at replacements costs. A comparison of depreciation aggregates between national accounts and representative data from financial statements, which is available in Germany only for selected industries, suggest a slight overestimation of national accounts depreciations. ${ }^{8}$ Likewise, in valuing inventories, the national accounts apply other concepts than those of financial accounts. ${ }^{9}$ Moreover, the national accounts measure financial transactions only with respect to interest income, rents, and distributed or retained profits. They do not take into account all other items of the financial or extraordinary result in the firms' income statement of financial or tax accounting, such as capital gains and losses, neither unrealized nor realized, gains and losses from mergers and reorganizations, restructuring and reorganization costs, or losses from extraordinary damage. Furthermore, national accounts neglect provisions, e.g., for pensions, or for uncertain obligations, warranties, expected losses, etc.

All these conceptual divergences might cause considerable differences in the income accrued in a single year. However, as these differences finally result from different timing schemes of cash flows, they might offset over time, especially in the long run (see also Heckemeyer and Spengel, 2008: 41). For instance, the rise of tax base erosion in the mid-nineties might be significantly caused by the tax incentives for East Germany such as the accelerated depreciation schemes. However, the higher depreciation allowances deducted in the first years after investment would clearly reduce the depreciation allowances in the following years, and thus increase the taxable income compared to an income accrual over time, for which straight-line depreciation is applied. Therefore, the mentioned differences in income concepts could only explain the observed gap in income aggregates as the firms' tax planning strategies have increasingly utilized opportunities for generating hidden reserves (see below, section 4.2).

With respect to tax exemptions, we correct for the income of the central reserve bank and the non-taxable subsidies (see above, Section 3.2). There are some other institutions included in the corporate sector of the national accounts that are exempted from taxation, for instance public utilities (sewage and waste disposal, street cleaning, social and cultural services) or non-profit institutions. The latter are included in the corporate sector only if they supply their

8 Deutsche Bundesbank provides a statistic on the financial statements of German enterprises, http://www.bundesbank.de/download/statistik/stat_sonder/statso5_1994_2003.en.pdf

9 Output stocks are valued at basic prices for national accounts purposes and input stocks at replacement cost for use in production. Paper profits which can arise in financial accounts when the price of stocks rises are thus eliminated in the national accounts. 
services predominately to corporations. It is hard to quantify the income generated by these institutions. However, due to their non-profit character they should not imply a significant income aggregate that impairs our analysis. It should be noted in this context that basically all public corporations in Germany, even public authorities, are liable to corporate income and local business taxation regarding their income from market-related business activities (Sec. 4 German Corporate Income Tax Code).

Corporate income could be overrated compared to tax statistics due to additions for underreporting in national accounts. On the basis of exhaustiveness checks, special additions for under-reporting are calculated for various areas of the production approach. Besides statistical cut-off limits, these adjustments mostly meet activities of the "hidden economy" such as tips or payments in kind, in-house production (in domestic gardens and own-account construction), and black labor (excluding illegal activities such as drug commerce, smuggling, gambling, etc.). In particular, those adjustments apply in the pertinent industries such as agriculture, skilled crafts and trades, construction, retail trade, or hotels and restaurants (Federal Statistical Office, 2009: 396). The income generated with these activities should widely accrue in the household sector, as compensation of employees or self-employed income. However, due to the residual determination of the entrepreneurial income for non-financial corporations and households altogether and the rough apportionment of the resulting income aggregate across both sectors afterwards (see the next section), even corporate income might slightly impaired by the estimations involved.

Beside the conceptual and institutional divergences one should take into account that, unlike other countries, Germany's national accounts do not utilize an independent bottom-up calculation of the entrepreneurial income for the total economy (Federal Statistical Office, 2009: 175). There is no data available from financial or tax accounting that is representative and sufficient detailed to allow such calculations in terms of the national account concept. Actually, the net operating surplus (including the mixed income) of the non-financial corporations and households is determined residually from gross national income (GNI), i.e., by subtracting consumption of fixed capital, taxes on production less other subsidies, and the compensation of employees. An independent bottom-up income calculation is only realized for the financial corporations (S.12), based on the comprehensive banking statistics of the Deutsche Bundesbank, and for the government sector (S.14), based on public budget accounting. The remaining business income is allocated to the non-financial corporations and households by rough estimates. Thus, all the estimation risks regarding GNI as well as the other income 
components including the households' share in entrepreneurial income might impair the residual that is assigned to corporations.

The estimation error involved is hard to quantify. The German Federal Statistical Office (2009: 374) reports "balancing differences" for the GDP accounting results according to the production and expenditure approaches that range up to 2 percent of GDP. With respect to the production approach of the GDP calculations, data problems arise with industries in the service sector, for which often no reliable accounting data is available, in particular for industries with a high share of small companies. For the expenditure approach data problems and estimation risks might have an impact in particular on the households' final consumption expenditure and the changes in inventories (Görzig and Schmidt-Faber, 2001).

If we, for instance, set the estimation risks involved here up to 2 percent of GDP, which amounted to Euro 50 billion per year in 2008, a considerable share of the observed gap in corporate income could result from an overestimation of the entrepreneurial income in national accounts. The implicit tax rates calculated above (Table 3) would be higher by almost 3 percentage points in 2007-08. Such an estimation error would imply, however, that either both GDP and GNI are accordingly overestimated, or the other income components are underestimated. Moreover, the estimation error in national accounts could also imply an underestimation of macroeconomic corporate income, which would increase the gap in the corporate income aggregates. In any case, there is no evidence that the continuous trend of tax base erosion is simply the result of a systematic overestimation of corporate income in national accounts.

\section{Economic Backgrounds}

\subsection{Corporate Tax Losses by Industries}

Before discussing selected economic backgrounds in order to shed more light on the presumptive corporate tax base erosion in Germany, we closer look at the importance of corporate tax losses by industrial composition, reported in the tax statistics waves. According to a similar approach by Altshuler et al. (2008), we measure the importance of losses by the ratio of losses (total income for firms with negative income) to positive income (total income for firms with positive income), each calculated at the level of adjusted gross income ("Gesamtbetrag der Einkünfte”), and both by firms liable to corporate income tax (Table 5) and by partnerships 
(Table 6). The corporate income tax statistics also reports the end-of-year stock of tax loss carryforwards, which we also put into relation to positive income of that year (Table 5).

Table 5 Tax losses and loss carryforwards in relation to taxable income, 1992-2007 of taxpayers liable to corporate income tax by industrial composition

\begin{tabular}{|c|c|c|c|c|c|c|}
\hline & 1992 & 1995 & 1998 & 2001 & 2004 & 2007 \\
\hline \multicolumn{7}{|l|}{ Running losses ${ }^{1)}$ as $\%$ of running profits ${ }^{2)}$} \\
\hline Agriculture, forestry and fishing & 931 & 213 & 129 & 48 & 60 & 29 \\
\hline Mining and quarrying & 91 & 212 & 48 & 17 & 40 & 107 \\
\hline Manuf. of intermed./non-durable goods & 126 & 39 & 25 & 35 & 42 & 21 \\
\hline Manuf. of investment/durable goods & 97 & 132 & 36 & 45 & 50 & 19 \\
\hline Electricity, gas and water supply & 75 & 35 & 13 & 17 & 13 & 14 \\
\hline Construction & 190 & 98 & 79 & 100 & 73 & 46 \\
\hline Trade, maintenance and repair & 68 & 60 & 46 & 59 & 38 & 25 \\
\hline Hotels and restaurants & 402 & 165 & 128 & 91 & 145 & 83 \\
\hline Transport, storage and communication & 118 & 195 & 44 & 136 & 61 & 111 \\
\hline Financial intermediation & 19 & 5 & 5 & 52 & 39 & 17 \\
\hline Real estate and renting & 89 & 150 & 118 & 140 & 113 & 85 \\
\hline Business service activities & 62 & 107 & 40 & 113 & 62 & 36 \\
\hline Public and personal service activities & 138 & 119 & 103 & 106 & 96 & 77 \\
\hline Total & 84 & 67 & 36 & 72 & 53 & 34 \\
\hline \multicolumn{7}{|l|}{$\begin{array}{l}\text { Loss carryforwards end of year } \\
\text { as } \% \text { of running profits }{ }^{2)}\end{array}$} \\
\hline Agriculture, forestry and fishing & 2501 & 1703 & 1770 & 931 & 954 & \\
\hline Mining and quarrying & 224 & 1466 & 573 & 306 & 264 & \\
\hline Manuf. of intermed./non-durable goods & 289 & 231 & 229 & 250 & 336 & \\
\hline Manuf. of investment/durable goods & 229 & 530 & 218 & 320 & 373 & \\
\hline Electricity, gas and water supply & 417 & 244 & 172 & 139 & 160 & \\
\hline Construction & 464 & 301 & 405 & 592 & 715 & \\
\hline Trade, maintenance and repair & 156 & 256 & 251 & 292 & 287 & \\
\hline Hotels and restaurants & 844 & 715 & 776 & 586 & 1089 & \\
\hline Transport, storage and communication & 306 & 767 & 317 & 744 & 856 & \\
\hline Financial intermediation & 43 & 26 & 28 & 104 & 229 & \\
\hline Real estate and renting & 225 & 747 & 782 & 935 & 1306 & \\
\hline Business service activities & 166 & 372 & 204 & 319 & 518 & \\
\hline Public and personal service activities & 375 & 560 & 609 & 607 & 881 & \\
\hline Total & 205 & 291 & 228 & 328 & 469 & 354 \\
\hline \multicolumn{7}{|l|}{$\begin{array}{l}\text { For information: } \\
\text { Structure of running profits }{ }^{2)} \text { in } \%\end{array}$} \\
\hline Agriculture, forestry and fishing & 0.2 & 0.2 & 0.2 & 0.3 & 0.3 & 0.4 \\
\hline Mining and quarrying & 0.6 & 0.4 & 0.5 & 0.5 & 0.7 & 1.9 \\
\hline Manuf. of intermed./non-durable goods & 14.6 & 17.6 & 14.2 & 13.9 & 12.0 & 11.6 \\
\hline Manuf. of investment/durable goods & 8.7 & 11.6 & 17.5 & 14.7 & 14.2 & 16.8 \\
\hline Electricity, gas and water supply & 1.7 & 4.7 & 4.3 & 5.0 & 5.0 & 3.7 \\
\hline Construction & 5.1 & 4.0 & 2.6 & 2.5 & 2.4 & 2.2 \\
\hline Trade, maintenance and repair & 16.5 & 12.8 & 9.8 & 10.9 & 12.7 & 11.6 \\
\hline Hotels and restaurants & 2.2 & 0.5 & 0.3 & 0.5 & 0.4 & 0.4 \\
\hline Transport, storage and communication & 9.4 & 2.0 & 5.6 & 3.6 & 4.5 & 2.8 \\
\hline Financial intermediation & 21.9 & 25.5 & 20.9 & 14.5 & 15.4 & 13.4 \\
\hline Real estate and renting & 2.2 & 3.9 & 3.7 & 4.5 & 4.3 & 4.2 \\
\hline Business service activities & 11.4 & 14.0 & 17.7 & 25.7 & 24.2 & 28.1 \\
\hline Public and personal service activities & 5.6 & 2.8 & 2.7 & 3.4 & 3.9 & 3.0 \\
\hline Total & 100.0 & 100.0 & 100.0 & 100.0 & 100.0 & 100.0 \\
\hline
\end{tabular}


We were able to use the micro data of the tax statistics via the research data centers research data of the German statistical offices. Information for the year 1992 is not available for partnerships. For 2007, we used published tabulations, which do not include the stocks of tax loss carryforwards by industries.

Basically, the losses fluctuate heavily over the years observed. This might be influenced by the business cycle, by financial market valuations triggering off capital gains and losses, or by tax reforms. For instance, the rather high impact of losses in 1992 and 1995 might be influenced by the tax allowances granted for investments in East Germany. In 2001 and 2004, the lower macroeconomic performance, the downturn in stock-market prices, or the several tax reforms since 1999 might have had an impact. In 2007, the booming economy seems to have reduced the level of losses.

With respect to the incorporated firms liable to the corporate income tax, the following industries report loss importance above average: Real estate and renting, hotels and restaurants, business services, public and personal services, transport, storage and communication, and construction. Agriculture shows very high losses in the nineties, but has little importance for the corporate sector. The manufacturing sectors, the hotel and restaurant industries, the real estate industry, partly the energy and water suppliers, and the construction sector face rather high losses in 1992 and 1995. This is probably due to the tax allowances for investments in East Germany.

As of 2001, the loss importance was low in manufacturing, as well as in energy and water supply and trade. The financial industries report a rather low importance of losses in the nineties, whereas in 2001 and 2004 losses became significant, presumably due to capital losses from the bursting dotcom bubble. With respect to partnerships, higher losses are reported by the industries of transport, storage and communication, hotel and restaurants, and real estate, for the latter especially in 1995 and 1998.

Generally, it is hard to assess the underlying trends without using detailed information on the composition of the aggregate corporate income. As discussed in the following Section 4.2, there is no representative data available for Germany that allows a breakdown to the relevant components of financial accounting, in particular with respect to the operating result, to the financial result, to extraordinary effects like capital gains and losses, and to tax allowances. Thus, it is hard to isolate what the impact of the business cycle is, and what effects might have had asset revaluation, tax reforms, or tax base erosion phenomena. 
Table 6 Tax losses in relation to taxable income, 1995-2004 of partnerships by industrial composition

\begin{tabular}{|c|c|c|c|c|c|}
\hline & 1995 & 1998 & 2001 & 2004 & 2007 \\
\hline \multicolumn{6}{|l|}{ Running losses ${ }^{1)}$ as $\%$ of running profits ${ }^{2)}$} \\
\hline Agriculture, forestry and fishing & 24 & 11 & 16 & 11 & 18 \\
\hline Mining and quarrying & 7 & 18 & 12 & 11 & 11 \\
\hline Manuf. of intermed./non-durable goods & 24 & 16 & 27 & 19 & 12 \\
\hline Manuf. of investment/durable goods & 27 & 19 & 24 & 18 & 13 \\
\hline Electricity, gas and water supply & 40 & 61 & 142 & 60 & 28 \\
\hline Construction & 31 & 29 & 38 & 28 & 14 \\
\hline Trade, maintenance and repair & 28 & 21 & 30 & 14 & 12 \\
\hline Hotels and restaurants & 85 & 64 & 48 & 49 & 30 \\
\hline Transport, storage and communication & 103 & 51 & 160 & 94 & 43 \\
\hline Financial intermediation & 108 & 16 & 21 & 47 & 11 \\
\hline Real estate and renting & 273 & 99 & 75 & 47 & 25 \\
\hline Business service activities & 28 & 32 & 51 & 23 & 15 \\
\hline Public and personal service activities & 36 & 37 & 35 & 29 & 36 \\
\hline Total & 64 & 39 & 45 & 29 & 18 \\
\hline \multicolumn{6}{|l|}{$\begin{array}{l}\text { For information: } \\
\text { Structure of running profits }{ }^{2)} \text { in } \%\end{array}$} \\
\hline Agriculture, forestry and fishing & 1.1 & 1.5 & 1.8 & 1.5 & 0.3 \\
\hline Mining and quarrying & 1.8 & 0.8 & 1.0 & 0.7 & 0.7 \\
\hline Manuf. of intermed./non-durable goods & 18.5 & 16.0 & 14.3 & 12.7 & 14.2 \\
\hline Manuf. of investment/durable goods & 12.1 & 11.5 & 13.3 & 10.0 & 13.6 \\
\hline Electricity, gas and water supply & 1.8 & 1.4 & 1.0 & 1.5 & 3.1 \\
\hline Construction & 5.0 & 3.7 & 2.8 & 2.4 & 2.8 \\
\hline Trade, maintenance and repair & 17.2 & 16.3 & 15.0 & 14.6 & 14.7 \\
\hline Hotels and restaurants & 1.1 & 0.9 & 0.9 & 0.7 & 1.0 \\
\hline Transport, storage and communication & 3.0 & 4.5 & 2.4 & 3.3 & 4.4 \\
\hline Financial intermediation & 0.9 & 1.6 & 3.2 & 1.8 & 3.0 \\
\hline Real estate and renting & 13.1 & 14.0 & 15.9 & 15.7 & 16.6 \\
\hline Business service activities & 15.0 & 17.7 & 18.2 & 23.4 & 21.0 \\
\hline Public and personal service activities & 9.5 & 10.0 & 10.3 & 11.6 & 4.7 \\
\hline Total & 100.0 & 100.0 & 100.0 & 100.0 & 100.0 \\
\hline
\end{tabular}

A brief look at the structural change of the industrial composition in Germany since 1991, measured by the gross value added from national accounts, could give some further clues to the backgrounds of tax base erosion trends (Figure 7). Since 1991, the shares of manufacturing and trade decreased. These are sectors with lower rations of tax losses over income. Under the stronger loss-making industries, the construction sector lost importance. Rising shares can be observed for the real estate industry, the business related services, and the personal service activities. In particular, real estate activities are often running high tax losses. 
Figure 7 Gross value added at current prices by industrial composition, 1991-2011 structure in percent

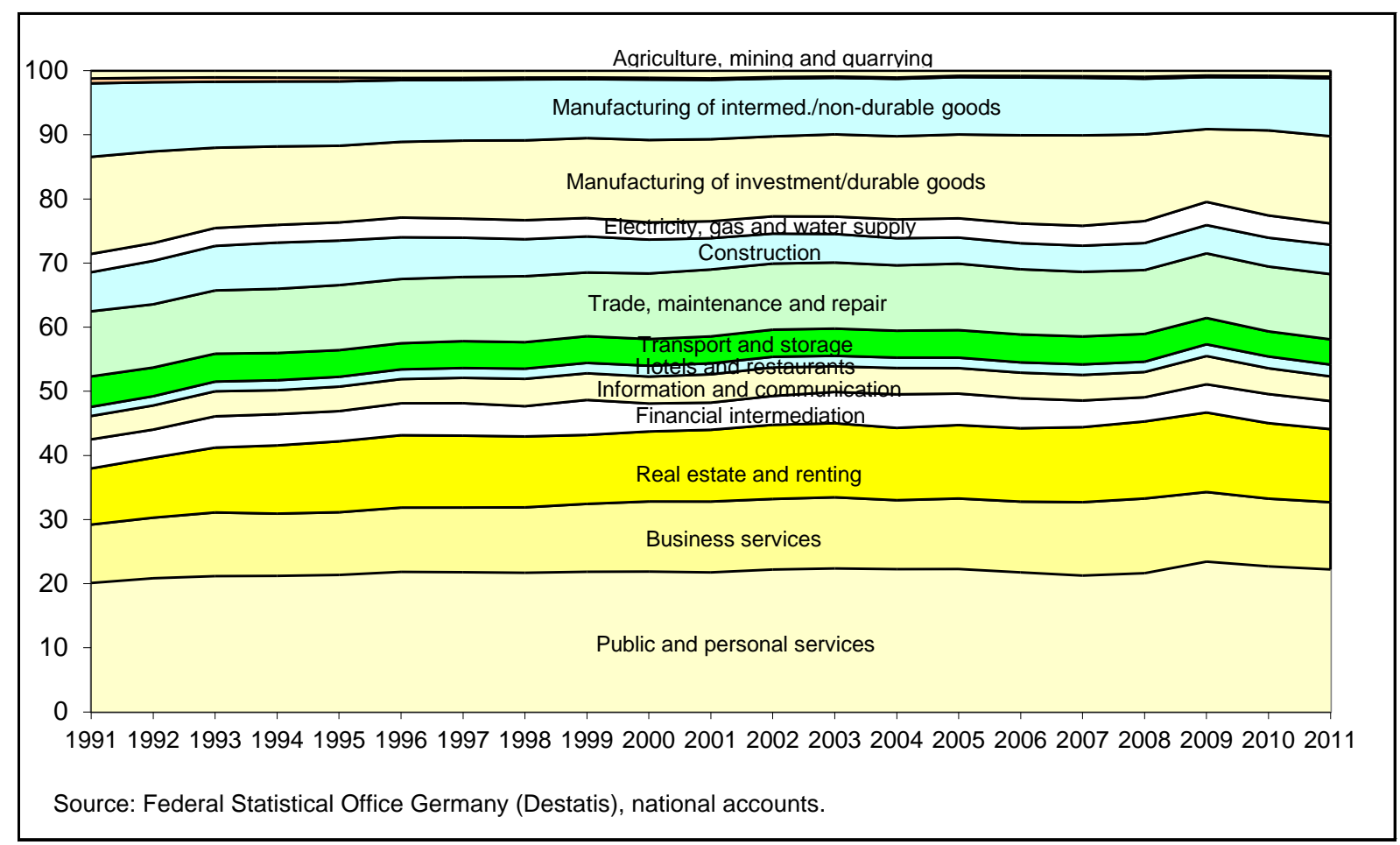

\subsection{Insufficient Data from Financial Accounting}

In order to look behind the aggregate trends of corporate tax base erosion and tax losses observed above, it suggests itself to scrutinize the firms' income determination components based on reliable data sets. First, one should analyze the operating result of the corporate sector, i.e., the result from ordinary activities less the financial result. Broadly speaking, this figure represents the firms' surplus from "real economic" activities, before taking into account financial transactions. Therefore, it is good comparable with the net operating surplus measured in national accounts (ESA 95 Code: B.2n). Second, the financial result as well as the balance sheet information on capital gives an impression on the financing activities, including write-downs of financial assets. These data should be separated by transactions with affiliated companies, and others. Third, the extraordinary result encompasses capital gains and losses from sales of assets, from mergers, restructurings and reorganizations, from extraordinary damages, and from other discontinued transactions. Generally, one should collect the underlying information as detailed as possible, in order to capture tax provisions that refer to single items, for instance, accelerated depreciation schemes for certain categories of assets, or provisions for certain issues.

As already mentioned in Section 3.4, there is no information system in Germany that includes sufficient detailed data from financial and tax accounting so far. The assessment of business 
taxes in Germany collects only those items from the firms' tax accounting that are immediately necessary to determine the tax liability. It starts from the net income/net loss for the financial year before appropriation, which already includes all items from the ordinary and extraordinary result. In addition, the tax returns only include those items that are required for the tax assessment, such as the additions and reductions for the calculation of the local business tax base, or the non-deductible expenses for the corporate income tax. Thus, the business tax statistics in Germany do not allow further investigation of potential tax base erosion, in contrast to countries like the UK or the USA (for the latter, see Altshuler et al., 2008).

Published financial statements, in particular the income statements, are only available for larger incorporated firms, according to the publication provisions of German commercial law. Although these firms should comprise a large share of business taxation, it is hard to assess the representativeness of such data bases. Even larger firms that are part of an affiliated group are not obliged to publish a financial statement, and often don't do so. Moreover, firms are only committed to disclose the main components of the balance sheet and the income statements. Therefore, results available from the DAFNE data base provided by the Bureau van Dijk, the Hoppenstedt data base, or the statistics of financial statements of the Deutsche Bundesbank (2012a) do not give sufficient detailed information and should be treated with caution with respect to representativity. Furthermore, financial accounting data does not include specific adjustments for tax purposes, especially with respect to asset valuation or allocation of provisions.

Nevertheless, such information should be used in order to shed more light on the issues discussed here. It is quite likely that the opportunities to create hidden reserves (e.g., by the lowest value and the recognition-of-loss principle, or by accelerated depreciation schemes) in combination with tax-preferred treatment of capital gains could explain a considerable part of the tax base erosion. Thus, even rough information could give some impression on the driving forces behind. As of 2012, German firms are obliged to transfer electronically various items of the tax accounting to the fiscal authorities ("E-Tax Balance Sheet”). This information should be utilized for tax statistics and academic research (see Bach et al., 2008, Luh, 1996).

\subsection{Tax Avoidance Strategies of Multinational Firms}

When we published a first study on tax revenue and corporate income in January 2007 (Bach and Dwenger, 2007), which comprised a preliminary version of the approach presented in Section 3, the results caused some stir. Against the background of the public and parliamen- 
tary debates on the business tax reform of 2008, the observed gap between the macroeconomic corporate income and the taxable income was widely discussed in the context of international tax avoidance, although our research gave no specific hints to these implications. ${ }^{10}$

Actually, there is rising anecdotal and some empirical evidence that the advance in economic internationalization increasingly enables profit shifting at the expense of German tax revenue (see, e.g., OECD, 2013, 2011, Buettner and Wamser, 2013, Wamser and Overesch, 2010, Weichenrieder, 2009). This is plausible in light of the high statutory tax rates in international comparison that were applied in Germany, at least up to 2007. Specifically, multinational firms might utilize strategies in the field of transfer pricing, thin capitalization, allocation of royalties, or the location of business "functions" such as R\&D, marketing, distribution, patents, and software. However, these issues can explain parts of the tax base erosion, measured above as difference between macroeconomic corporate income and taxable income, only insofar as the macroeconomic income figures are not impaired in the same way. For instance, transfer pricing strategies of firms should reduce the valuations of transactions or stocks in both tax accounting and internal financial accounting. As business surveys used for national accounts rely on the latter data sources, macroeconomic business income aggregates should also be underestimated. Only insofar as national accounts statistics consistently integrate all the available data sources under the constraint of the accounting identities of the macroeconomic circuit, they might disclose such income components escaping taxation. However, as pointed out above (Section 3.4), such residual estimates might be flawed by all other estimation errors.

In any case, since detailed micro data sets from the firms' tax or financial accounting are not available for Germany, it is hard to assess the specific impact of international tax avoidance on German tax base erosion. The following paragraphs seek to assess some potential impact from selected issues of international tax avoidance.

A rough estimation on the potential revenue effect of transfer pricing in the case of goods and services traded internationally is given in Table 7 (see also the similar approaches of Schaumburg, 2006, and Jonas, 2009). Using the national accounts statistics, we calculate the foreign trade volume of Germany by adding up exports and imports. Yet there is no empirical evi-

10 Our results have been explicitly quoted in the statement of the bill introduced by the then "great coalition" parliamentary fractions as evidence on the presumable tax base erosion in Germany, which calls for a cut in 
dence on the extent of intra-firm trade for Germany. According to data form other Western OECD countries, the shares of intra-firm trade of affiliates under foreign seem to be rather high (OECD, 2005: 181, Dunning and Lundan, 2008: 482). In order to illustrate the potential impact on tax base and tax revenue, we simply assume a 30 percent share of intra-firm trade based on the entire foreign trade volume. Moreover, we suggest an average level of price adjustments by 3 percent, and an average business tax rate of 30 percent for Germany.

Table 7 Estimation of the potential fiscal impact of transfer pricing based on exports, imports, and foreign trade volume of goods and services from national accounts, 1992-2010

\begin{tabular}{|c|c|c|c|c|c|c|c|c|c|}
\hline & 1992 & 1995 & 1998 & 2001 & 2004 & 2007 & 2008 & 2009 & 2010 \\
\hline Foreign trade volume & \multicolumn{9}{|c|}{ billion Euro } \\
\hline Exports of goods and services (fob) & 380 & 429 & 546 & 715 & $828 i$ & 1123 & 1169 & 984 & 1150 \\
\hline Imports of goods and services (cif) & 371 & 396 & 494 & 640 & $685 !$ & 918 & 976 & 833 & 977 \\
\hline Total & 750 & 824 & 1040 & 1355 & $1513 !$ & 2041 & 2145 & 1817 & 2127 \\
\hline Foreign trade volume & \multicolumn{9}{|c|}{ as percent of GDP } \\
\hline Exports of goods and services (fob) & 23.0 & 23.2 & 27.9 & 34.0 & $37.7 !$ & 46.2 & 47.2 & 41.5 & 46.1 \\
\hline Imports of goods and services (cif) & 22.5 & 21.4 & 25.2 & 30.4 & 31.2 & 37.8 & 39.4 & 35.1 & 39.1 \\
\hline Total & 45.5 & 44.6 & 53.1 & 64.5 & $68.9 !$ & 84.1 & 86.7 & 76.5 & 85.2 \\
\hline Potential revenue impact of transfer pricing & \multicolumn{9}{|c|}{ billion Euro } \\
\hline Assumption: Share of intra-firm trade $30.0 \%$ & 225.1 & 247.3 & 312.1 & 406.4 & $453.9 !$ & 612.4 & 643.4 & 545.1 & 638.2 \\
\hline Assumption: Price adjustments & 6.8 & 7.4 & 9.4 & 12.2 & $13.6 !$ & 18.4 & 19.3 & 16.4 & 19.1 \\
\hline Impact on domestic business tax revenue & & & & & & & & & \\
\hline with a average tax rate of & 2.0 & 2.2 & 2.8 & 3.7 & $4.1 !$ & 5.5 & 5.8 & 4.9 & 5.7 \\
\hline
\end{tabular}

Beside the ad-hoc assumptions on the share of intra-firm trade and the extent of price adjustments, the rapidly increasing foreign trade volume since the mid-nineties underlines the rising impact of the internationalization for the German economy. From 1995 to 2008, the ratio of foreign trade volume over GDP nearly doubles. The potential for transfer pricing should have increased correspondingly. Together with the presumably high and rising share of intra-firm trade, this might suggest some relevance for tax base erosion and tax revenue. However, transfer pricing regulations have been restricted step by step over the last decade, in particular by the introduction of statutory documentation regulations as of 2003. Finally, further conclusions on the precise quantities involved are hard to draw due to the lack of detailed data.

tax rates and broadening the tax base, see Deutscher Bundestag (2007: 29). See also Heckemeyer and Spengel (2008), and Jonas (2009). 
Information on income streams and capital stocks involved with direct investment is provided by the balance of payments statistics of the Deutsche Bundesbank (2013). ${ }^{11}$ The main figures of the income from direct investment are illustrated in Table 8, both for outbound investments (i.e., investments of residents abroad) and for inbound investments (i.e., investments of foreigners in Germany). The information mainly stems from the foreign direct investment stock statistics of the Deutsche Bundesbank (2012b), which is based on mandatory reports by enterprises and individuals on their direct investments abroad or in Germany. ${ }^{12}$

The statistics mainly confirm what one would expect with respect to the incentives of business taxation. For German outbound investment, debt financing plays a minor role, as shown by the low share of interest income on shareholder loans. The reported profit income markedly increased over the last decade. In particular, the retention of profits from investments abroad rose strongly over the last years, whereas in the first years of the last decade foreign reserves have been withdrawn on average. In contrast, foreign direct investments in Germany are much more leveraged by shareholder loans, as the figures on interest income in relation to profits suggest. The reinvestment of earnings also does not play an important role.

These results are in line with the common notion that debt finance was rather attractive in Germany for tax reasons. Interest expenses are basically deductible from the income tax base and only partly liable to the local business tax (by 25 percent, by 50 percent until 2007). Regarding the high statutory tax rates, it was attractive to finance home investment by debts from abroad up to the limits of thin capitalization rules. The latter have been strengthened step

11 According to the definition of the Deutsche Bundesbank (2012b: 19), direct investment are financial operations with German and foreign enterprises in which the investor directly holds 10 percent or more of the shares or voting rights (up to end-1989 25 percent or more, from 1990 to end-1998 more than 20 percent); including branches and permanent establishments. Up to end-1995 direct investments comprise capital shares, including reserves, profits and losses carried forward, and long-term loans. Direct investments also include all investments in real property.

12 According to the applicable German foreign trade and payments regulation, reports are required to be submitted

(1) for German foreign direct investment by German enterprises and households which, on the reporting date, have direct (primary) holdings of 10 percent or more, or direct and indirect (secondary) holdings totaling more than 50 percent of the capital shares or voting rights in an enterprise abroad which has a balance sheet total of more than (the equivalent of) Euro 3 million. Reports are also required of German enterprises that maintain branch offices or permanent establishments abroad with operating assets in excess of Euro 3 million.

(2) for foreign direct investment in Germany by every German enterprise with a balance sheet total of more than Euro 3 million in which a non-resident (or several economically linked non-residents) holds 10 percent or more of the shares or voting rights in the German enterprise on the balance sheet date. Reports are also required of non-residents' branch offices or permanent establishments in Germany with operating assets in excess of Euro 3 million. 
by step, in particular with the introduction of the interest limitation (“Zinsschranke”) as of 2008.

Table 8 Income from direct investment, interest on shareholder loans, 1999-2010 billion Euro

\begin{tabular}{|c|c|c|c|c|c|c|c|c|c|c|c|c|}
\hline & 1999 & 2000 & 2001 & 2002 & 2003 & 2004 & 2005 & 2006 & 2007 & 2008 & 2009 & 2010 \\
\hline \multicolumn{13}{|l|}{ German direct investment abroad (outbound) } \\
\hline Income from equity (excl. leasing and rents on land) & 10.5 & 12.2 & -0.7 & 5.0 & 11.7 & 36.4 & 43.4 & 54.7 & 59.1 & 14.1 & 43.7 & 57.4 \\
\hline Dividends and other distributed profits & 8.8 & 17.4 & 19.0 & 18.3 & 15.7 & 17.6 & 22.8 & 26.5 & 28.2 & 35.1 & 27.9 & 37.4 \\
\hline Undistributed (reinvested) earnings & 1.7 & -5.2 & -19.8 & -13.3 & -4.0 & 18.8 & 20.6 & 28.3 & 30.9 & -21.0 & 15.8 & 20.0 \\
\hline Interest on shareholder loans & 2.8 & 5.2 & 3.9 & 2.4 & 1.6 & 2.2 & 2.8 & 4.0 & 6.4 & 7.3 & 7.2 & 7.5 \\
\hline \multicolumn{13}{|l|}{ Foreign direct investment in Germany (inbound) } \\
\hline Income from equity (excl. leasing and rents on land) & 4.8 & 3.3 & -9.6 & 5.7 & 8.6 & 9.3 & 19.4 & 18.8 & 29.3 & -0.6 & 4.6 & 22.1 \\
\hline Dividends and other distributed profits & 10.6 & 10.2 & 11.6 & 12.7 & 11.9 & 13.3 & 16.1 & 19.1 & 23.8 & 21.9 & 16.0 & 18.8 \\
\hline Undistributed (reinvested) earnings & -5.8 & -6.9 & -21.3 & -7.0 & -3.3 & -4.1 & 3.3 & -0.4 & 5.5 & -22.5 & -11.4 & 3.3 \\
\hline Interest on shareholder loans & 4.4 & 10.8 & 14.4 & 14.7 & 14.0 & 11.9 & 12.0 & 14.3 & 17.6 & 16.1 & 16.0 & 18.4 \\
\hline
\end{tabular}

Due to the former full imputation system of the corporate income tax, there were incentives for multinationals to primarily distribute domestic corporate income, as the tax rates on distributed income were much lower compared to the tax rates on retained income. The dividend distributions of foreign subsidiaries were often used for internal financing. They were exempted from domestic taxation in most cases according to Germany's double taxation provisions, but only as long as they were not passed to domestic shareholders. This was regarded as a certain break against aggressive profit shifting to abroad, but ended with the transition to the classical system of corporate income taxation. The markedly increase in retained profits from direct investment abroad might be influenced by these tax implications.

In order to shed more light on the tax incentives for cross-border finance one should analyze the data in depth. Unlike the general data limitations on financial and tax accounting data, the foreign direct investment stock statistics of the Bundesbank is accessible to scientific research, even on the level of the micro data. Studies show an impact of tax rates and thin capitalization regulations on finance decisions of the firms (see Ramb and Weichenrieder, 2005, Wamser and Overesch, 2010, Buettner et al., 2008, Weichenrieder and Windischbauer, 2008, Weichenrieder, 2009, Weichenrieder and Ruf, 2012, Buettner and Wamser, 2013).

The balance of payments statistics also accounts the cross-border receipts and expenditure for patents and licenses (Table 9). Royalties for the use of such property rights are often deemed as vehicle for profit shifting, as it is rather reasonable to transfer them to foreign locations. International tax law usually allocates the right to tax to the owner's country of residence, which is also applied by Germany in most cases. The figures of Table 9 indicate only a slight net outflow of royalty income in Germany if one balances receipts and expenditure up to 
2008. In 2009-10, the balance actually turned to net inflows. Changing double taxation provisions in favor of the country where the property rights are used would insofar not raise much tax revenue in Germany, or even involve revenue losses. This does not imply that there is no profit shifting, however. Given the strongholds in technological capabilities of many German firms, in particular in the manufacturing industries and some business related service sectors, one might expect that there is a noticeable net inflow of royalty income to Germany.

Table 9 Cross-border receipts and expenditure for patents and licenses ${ }^{1)}$, 1999-2010 billion Euro

\begin{tabular}{|l|r|r|r|r|r|r|r|r|r|r|r|r|}
\hline & 1999 & 2000 & 2001 & 2002 & 2003 & 2004 & 2005 & 2006 & 2007 & 2008 & 2009 & 2010 \\
\hline Receipts & 2.9 & 3.2 & 3.7 & 4.1 & 4.0 & 4.4 & 5.7 & 5.6 & 6.2 & 7.5 & 12.9 & 11.2 \\
Expenditure & 4.8 & 6.2 & 6.1 & 5.6 & 4.7 & 4.7 & 6.9 & 7.4 & 8.2 & 8.8 & 12.7 & 10.0 \\
Balance & -1.9 & -3.0 & -2.4 & -1.5 & -0.7 & -0.3 & -1.2 & -1.9 & -2.0 & -1.3 & 0.2 & 1.2 \\
\hline 1) Industrial and other property rights. \\
Source: Deutsche Bundesbank, balance of payments statistics. \\
\hline
\end{tabular}

To sum up, international tax avoidance might be a reason of rising importance for tax base erosion over the last decades. Due to the lack of reliable data from tax or financial accounting it is hard to draw precise conclusions on the quantities involved. The figures derived from the foreign trade and payments statistics presented in this section suggest that profit shifting to abroad might easily sum up to a couple of Euro 10 billion. However, there is no evidence that international tax avoidance largely causes the observed gap between macroeconomic corporate income and the corporate tax base of Euro 90 billion and more.

\subsection{Tax Avoidance of SMEs and Impact of Tax Enforcement}

Small and medium-sized enterprises (SMEs) typically do not benefit so much from the prospects of tax avoidance in the course of internationalization. However, as their own tax haven, they could try to set off private consumption expenditures against tax liability. The regulations of separating business expenses from private expenses are rather intricate and hard to retrace in practice, thus inviting to manipulations. In particular, this refers to cars and vans available for private use, traveling and subsistence expenses, entertaining expenses, remunerations and withdrawals in non-cash form, and beneficial employment contracts, loan arrangements or other transactions with spouses, relatives, partners, shareholders, or other related parties. All in all, considerable amounts might be involved here. For instance, there are 5 million company cars registered in Germany, of which 3 million are available for private use. Similar to the issues of transfer pricing and thin capitalization discussed in the preceding section, there might be some leeway to manipulate the respective business transactions for tax 
saving. However, it is hard to quantify the impact of these issues to the corporate tax base due to the lack of reliable data.

In the case of firms liable to the corporate income tax, the contractual compensation of managers is deductible from the tax base even if the managers are shareholders of the firm, which is often the case for SMEs. The compensation of owner-managers is taxed as wage income by the personal income tax, as far it is deemed as appropriate. Since the payroll information collected in business surveys and national accounts also include these compensations, insofar the corporate income in national accounts should not diverge from the corporations' taxable income. $^{13}$

Another relevant issue in this field could be lax tax enforcement. There are rising complaints that fiscal authorities in Germany increasingly fail to enforce the tax law effectively due to shortage of staff and organizational deficits (Bundesrechnungshof, 2006). This is particular true with respect to the complex tax law and assessment procedures in the field of business taxation. In this context, disincentives of the German fiscal federalism might also play a significant role. In Germany, the administration of direct taxes is the matter of the state governments ("Länder"), although the lager part of the tax revenue is transferred to the federal state and the municipalities. Together with highly redistributive fiscal equalization schemes this generates clear disincentives for the state governments to fully utilize the tax base (Plachta, 2008: 80).

Similar to the impact of tax avoidance strategies of multinational firms discussed above, the issues discussed here could only insofar contribute to explain the measured gap between taxable corporate income and macroeconomic corporate income as the latter is not impaired in the same way. In the case of manipulated business expenses mentioned above, national accounts might factor these items into private consumption, which would correspondingly increase macroeconomic corporate income. In other cases, for instance with hidden private use of company cars, the business surveys and thus the national accounts might be blurred as well, since the respective numbers are drawn from the firms’ bookkeeping.

13 Actually, the aggregate wage income of national accounts exceeds the wage income reported in the personal income tax statistics by 2.3 percent in 2007. This difference can be well explained by tax-free or lump-sum taxed wages of short-time employment, draftees, etc., which are not registered individually by the tax authorities. 


\subsection{Decreasing Effective Tax Rates Due to the Decline in Inflation}

Thanks to the Bundesbank's notorious monetary policy of providing a stable currency, the inflation rates in Germany have been significantly lower compared to other OECD countries over the last decades (Table 10). Moreover, as in most other countries, inflation rates markedly declined since the seventies, according to the changes in monetary and macroeconomic policy. With respect to the issues of business taxation discussed here, the relevant implication is that lower inflation rates increase the real value of capital allowances, and reduce the taxation of mere "paper profits” from inflation, respectively. Notably, German tax law consequently applies the "nominal value principle”. There are no adjustments for inflation, neither for depreciation allowances, nor for the valuation of other assets, provisions, capital gains, or loss-carryforwards.

Table 10 Price indices in international comparison, 1971-2010

yearly average changes in percent

\begin{tabular}{|c|c|c|c|c|c|c|c|c|}
\hline & $\begin{array}{c}1971- \\
1975\end{array}$ & $\begin{array}{c}1976- \\
1980\end{array}$ & $\begin{array}{c}1981- \\
1985\end{array}$ & $\begin{array}{c}1986- \\
1990\end{array}$ & $\begin{array}{c}1991- \\
1995\end{array}$ & $\begin{array}{c}1996- \\
2000\end{array}$ & $\begin{array}{c}2001- \\
2005\end{array}$ & $\begin{array}{l}2006- \\
2010\end{array}$ \\
\hline \multicolumn{9}{|l|}{ Deflator gross domestic product } \\
\hline Germany & 6.3 & 3.9 & 3.1 & 2.4 & 3.2 & 0.2 & 1.1 & 1.0 \\
\hline OECD Europe & 8.1 & 8.0 & 6.7 & 4.2 & 3.4 & 2.2 & 3.5 & 2.7 \\
\hline OECD Total & 8.4 & 7.2 & 5.0 & 3.4 & 2.5 & 3.6 & 2.6 & 2.0 \\
\hline Difference Germany-OECD Europe & -1.8 & -4.1 & -3.5 & -1.8 & -0.2 & -2.0 & -2.4 & -1.8 \\
\hline Difference Germany-OECD Total & -2.1 & -3.3 & -1.9 & -0.9 & 0.7 & -3.4 & -1.5 & -1.0 \\
\hline \multicolumn{9}{|l|}{ Consumer price index, all items } \\
\hline Germany & 6.1 & 4.0 & 3.9 & 1.4 & 3.6 & 1.3 & 1.5 & 1.6 \\
\hline OECD Europe & 10.0 & 12.7 & 10.2 & 6.6 & 8.1 & 6.4 & 3.5 & 2.5 \\
\hline G7 & 8.3 & 9.1 & 6.1 & 3.5 & 3.0 & 1.9 & 1.9 & 1.8 \\
\hline OECD Total & 8.9 & 10.8 & 9.5 & 7.4 & 5.4 & 4.4 & 2.7 & 2.2 \\
\hline Difference Germany-OECD Europe & -3.9 & -8.7 & -6.3 & -5.2 & -4.6 & -5.2 & -2.0 & -0.9 \\
\hline Difference Germany-OECD Total & -2.8 & -6.8 & -5.7 & -6.0 & -1.8 & -3.1 & -1.2 & -0.6 \\
\hline
\end{tabular}

While the average inflation rates in Germany ranged around 2 to 3 percent over the eighties up to the mid-nineties, measured by the GDP deflator of national accounts, they decreased to around 1 percent over the last decade. Even if we take into account a downward distortion due to the macroeconomic stagnation of the years 2001-05, Germany's inflation rates decreased by at least 1 percentage point compared to the level of the eighties and the first half of the nineties, and much stronger compared to the seventies. In relation to the OECD average inflation rate, the inflation rates in Germany have been lower by 1.0 to 1.5 percent over the last decade, measured by the GDP deflator. In the seventies and early eighties, the difference was much higher. 
Neither the retrenchment in inflation over time nor the backlog in inflation compared to other countries could explain the level of tax base erosion in Germany discussed in the previous sections. However, this might explain, ceteris paribus, a significant decrease in real tax base and effective tax rates over time or compared to other countries. For a rough estimation of the effects involved, we simply rely on the corporations' net fixed capital stock at current purchasers' prices (i.e., at replacements cost) from German national accounts. This figure amounts to Euro 2,400 billion in 2004. That means that a decrease in the inflation rate by 1 percentage point would reduce the taxation of "paper profits" by Euro 24 billion per year, which equates to more than 1 percent of GDP, or 7.4 percent of the modified corporate income calculated above (see Section 3.2, Table 3). The effective tax rate for 2004 (see Table 3) would decrease by 1.3 percentage points.

\section{Summary and Conclusions}

Business income in Germany was taxed at relative high statutory tax rates over the last decades, at least up to 2007. Measures of effective tax rates, derived from simulation models following the approaches of King and Fullerton (1984) and Devereux and Griffith (1999, 2003), also indicate rather high levels of business taxation in Germany compared to other countries. At the same time, there was a rising presumption in tax policy that business taxation revenue lags behind economic performance and business income growth. Tax expenditures, European and international tax competition, and the effects of tax reform seem to impair business tax revenue. However, there is scarce empirical evidence on the economic issues involved.

For the first time for Germany we present comprehensive measures of the entire business taxation revenue and the tax base accrued in single tax years. We use representative data from the business tax statistics that collect the relevant information from the tax returns. For the personal income tax we estimate the portion of the tax liability falling on business income. Using detailed data form the income tax statistics we allocate the individual tax liability according to the share of business income in total income.

We compare the tax revenue and tax base reported in the business tax statistics with the macroeconomic income aggregates measured in the national accounts statistics. Based on a similar concept of the European Commission (2013), we derive a corporate income aggregate that approximates the actual taxable income as close as possible. Dividing the tax revenue by the 
macroeconomic corporate income aggregate, we calculate macroeconomic implicit tax rates on corporate income.

We find that the implicit tax rates on corporate income falling considerably short of statutory tax rates, as well as of effective tax rates discussed in the literature. Our estimations suggest that the average implicit tax rate on German corporate income was around 21 percent since 2001. A detailed comparison of the corporate income measured in national accounts with the corporate tax base reported in the tax statistics reveals a considerable gap that amounts to 4 percent of GDP and more in 2004. The gap has increased over the years up to 2007. For 2008, there is a marked decline due to the broadening of the tax base involved by the 2008 reform of business taxation back, but the gap still amounts to Euro 90 billion or 3.7 percent of GDP. With respect to the precise level of corporate tax base erosion in Germany these results should be treated with caution, due to some potential estimation risks of the entrepreneurial income aggregates of German national accounts. However, the high weight of losses reported in tax statistics emphasizes the presumptive tax base erosion. There are many firms running tax losses, the ratio of running losses over positive income is rather high. From 1992 to 2008, the stock of corporate income tax loss carryforwards increased by more than 340 percent to Euro 568 billion, which equates to 23 percent of GDP, or 3 times the positive adjusted gross income of that year. Real estate industry, hotels and restaurants, and business services show a higher importance of corporate tax losses. The broadening of the tax base involved by the 2008 reform of business taxation seems to have markedly reduced the gap between overall and taxable corporate income.

Due to the lack of reliable data from tax and financial accounting it is hard to give precise reasons for the presumptive tax base erosion and the high tax losses. International tax avoidance might be a cause, as anecdotal evidence and several empirical studies suggest. This is plausible in light of the high statutory tax rates in Germany and the advance in economic internationalization. However, cautious evidence from foreign trade and payments statistics indicates that this arguably explains only a minor part of the gap. Presumably, the opportunities to create hidden reserves, given by the income determination provisions in combination with tax-preferred treatment of capital gains, tax-saving strategies of small and medium-sized firms with respect to hidden private expenses, and lax tax enforcement could explain a considerable part of the tax base erosion. However, there is no information system in Germany that includes representative and sufficient detailed data from tax or financial accounting. 
In order to shed more light on these implications, detailed accounting information should be collected from the firms' tax assessment, which is on the way in Germany. Currently, the tax assessment procedures in Germany collect only those items from tax accounting that are immediately necessary to determine the tax liability. As of 2012, firms are obliged to transfer electronically various items of the tax accounting to the fiscal authorities. This information should be utilized for tax statistics and academic research (see Bach et al., 2008, Luh, 1996). This is a standard practice in other countries and would, by the way, substantially improve the information base for a direct calculation of corporate income in national accounts. ${ }^{14}$

14 See, e.g., Office for National Statistics UK (2000: 100), Statistics Netherlands, National Accounts Department (2008: 210), Statistics Sweden (2008: 125), or U.S. Department of Commerce, Bureau of Economic Analysis (2009: 3-13). 


\section{References}

Altshuler, Rosanne, Alan J. Auerbach, Michael Cooper, Matthew Knittel (2008): Understanding U.S. Corporate Tax Losses. NBER Working Paper No. 14405, October 2008.

http://www.nber.org/papers/w14405

Bach, Stefan, Hermann Buslei (2009): The Impact of Losses on Income Tax Revenue and Implicit Tax Rates of Different Income Sources. Evidence from Microsimulation Using Tax Statistics for Germany. DIW Berlin Discussion Paper 950. http://www.diw.de/documents/publikationen/73/diw 01.c.343857.de/dp950.pdf

Bach, Stefan, Hermann Buslei, Nadja Dwenger, Frank Fossen, Viktor Steiner (2008): Verbesserung der steuerstatistischen Informationssysteme zur Folgenabschätzung und Evaluierung steuerpolitischer Maßnahmen im Bereich der Unternehmensbesteuerung. DIW Berlin: Politikberatung kompakt 43. Berlin 2008.

http://www.diw.de/documents/publikationen/73/diw_01.c.83602.de/diwkompakt_2008-043.pdf

Bach, Stefan, Nadja Dwenger (2007): Unternehmensbesteuerung: Trotz hoher Steuersätze mäßiges Aufkommen. Wochenbericht des DIW Berlin Nr. 5/2007. http://www.diw.de/documents/publikationen/73/diw 01.c.55734.de/07-5-1.pdf

Becker, Johannes, Clemens Fuest (2004): A Backward-Looking Measure of the Effective Marginal Tax Burden on Investment. CESifo Working Paper No. 1342.

http://www.ifo.de/pls/guestci/download/CESifo\%20Working\%20Papers\%202004/CESifo\%20Working\% 20Papers\%20November\%202004/cesifo1_wp1342.pdf

Becker, Johannes, Clemens Fuest (2006): Ist Deutschland Hoch- oder Niedrigsteuerland? Der Versuch einer Synthese. Perspektiven der Wirtschaftspolitik 7, 35-42.

Buettner, Thiess, Georg Wamser (2009): Internal Debt and Multinational Profit Shifting - Empirical Evidence from Firm-Level Panel Data. National Tax Journal 66, 63-96.

http://ntj.tax.org/wwtax/ntjrec.nsf/175d710dffc186a385256a31007cb40f/ebeb56cf1b343df085257b35007 15ab7/\$FILE/A03_Buettner.pdf

Buettner, Thiess, Michael Overesch, Ulrich Schreiber, Georg Wamser (2008): The impact of thincapitalization rules on multinationals' financing and investment decisions. Deutsche Bundesbank Discussion Paper Series 1: Economic Studies. No 03/2008.

http://econstor.eu/bitstream/10419/19715/1/200803dkp.pdf

Bundesrechnungshof (2006): Probleme beim Vollzug der Steuergesetze. Empfehlungen des Präsidenten des Bundesrechnungshofes als Bundesbeauftragter für Wirtschaftlichkeit in der Verwaltung zur Verbesserung des Vollzuges der Steuergesetze in Deutschland. Schriftenreihe des Bundesbeauftragten für Wirtschaftlichkeit in der Verwaltung Band 13. Stuttgart: Kohlhammer. http://books.google.de/books?id=Y3P4l2yYhbUC\&printsec=frontcover\#v=onepage\&q=\&f=false

Deutsche Bundesbank (2012a): Extrapolated results from financial statements of German enterprises 2006 to 2011. Special Statistical Publication 5.

http://www.bundesbank.de/Redaktion/EN/Downloads/Statistics/Enterprises_Households/Corporate_Fina ncial_Statements/Statistical_Publication_5_Tables/statso5_2006_2011_en.xlsb? blob=publicationFile

Deutsche Bundesbank (2012b): Foreign direct investment stock statistics. Special Statistical Publication 10. April 2012.

http://www.bundesbank.de/Redaktion/EN/Downloads/Publications/Statistische_Sonderveroeffentlichung en/Statso_10/statso_10_foreign_direct_investment_stock_statistics.pdf?_blob=publicationFile

Deutsche Bundesbank (2013): Balance of payments statistics. April 2013. Statistical Supplement 3 to the Monthly Report

http://www.bundesbank.de/Redaktion/EN/Downloads/Publications/Statistical_Supplement_3/2013/2013 04_balance_of payments_statistics.pdf? blob=publicationFile

Deutscher Bundestag (2007): Entwurf eines Unternehmensteuerreformgesetzes 2008. Gesetzentwurf der Fraktionen der CDU/CSU und SPD. 27.03.2007. Deutscher Bundestag, Drucksache 16/4841. http://dipbt.bundestag.de/dip21/btd/16/048/1604841.pdf 
Devereux, Michael P., Rachel Griffith (1999): The taxation of discrete investment choices (Revision 2). Institute for Fiscal Studies, Working Paper Series No. W98/16.

http://www.ifs.org.uk/wps/wp9816.pdf

Devereux, Michael P., Rachel Griffith (2003): Evaluating tax policy for location decisions. International Tax and Public Finance 10, 107-126.

Devereux, Michael P., Rachel Griffith, Alexander Klemm (2002): Corporate Income Tax Reforms and International Tax Competition. Economic Policy 17, 451-495.

Devereux, Michael P., Rachel Griffith, Alexander Klemm (2004): Why has the UK corporation tax raised so much revenue? Fiscal Studies 25, 367-388. http://www.ifs.org.uk/wps/wp0404.pdf

Devereux, Michael P., Christina Elschner, Dieter Endres, Jost H. Heckemeyer, Michael Overesch, Ulrich Schreiber, Christoph Spengel (2008): Effective levels of company taxation within an enlarged EU. Report prepared for the European Commission, TAXUD/2005/DE/3 10.

http://ec.europa.eu/taxation_customs/resources/documents/taxation/gen_info/economic_analysis/economi c studies/effective_levels report.pdf

Devereux, Michael P., Christina Elschner, Dieter Endres, Christoph Spengel (2009): Effective Tax levels Using The Devereux /Griffith Methodology. Project for the EU Commission, TAXUD/2008/CC/099. Report 2009.

http://ec.europa.eu/taxation_customs/resources/documents/common/publications/studies/etr_company_ta $\underline{\text { x.pdf }}$

Dunning, John H., Sarianna M. Lundan (2008): Multinational Enterprises and the Global Economy. Cheltenham: Edward Elgar. http://books.google.de/books?id=xIk3fF2z5KcC\&source=gbs_navlinks_s

Egger, Peter, Simon Loretz, Michael Pfaffermayr, Hannes Winner (2009): Firm-specifc Forwardlooking Effective Tax Rates. International Tax and Public Finance 16, 850-870. http://www.sbs.ox.ac.uk/centres/tax/Documents/working_papers/WP0811.pdf

Elschner, Christina, Werner Vanborren (2009): Corporate Effective Tax Rates in an Enlarged European Union. Taxation Papers 14, Directorate General Taxation and Customs Union, European Commission.

http://ec.europa.eu/taxation_customs/resources/documents/taxation/gen_info/economic analysis/tax pape rs/taxation_paper_14_en.pdf

European Commission (2001): Company Taxation in the Internal Market. Commission staff working paper, COM(2001)582 final. Brussels, 23.10.2001, SEC(2001) 1681.

http://ec.europa.eu/taxation_customs/resources/documents/company_tax_study_en.pdf

European Commission (2011): Taxation trends in the European Union. Data for the EU Member States, Iceland and Norway. 2011 edition. Luxembourg.

http://ec.europa.eu/taxation_customs/resources/documents/taxation/gen_info/economic analysis/tax stru ctures/2011/report_2011_en.pdf

European Commission (2013): Taxation trends in the European Union. Data for the EU Member States, Iceland and Norway. 2013 edition. Luxembourg.

http://ec.europa.eu/taxation_customs/resources/documents/taxation/gen_info/economic_analysis/tax_stru ctures/2013/report.pdf

Federal Statistical Office (2009): National Accounts. Gross Domestic Product in Germany in accordance with ESA 1995. Methods and Sources. Version following the major revision 2005. Subject-matter series 18, series S. 22. Wiesbaden.

https://www.destatis.de/DE/Publikationen/Thematisch/VolkswirtschaftlicheGesamtrechnungen/Inlandspr odukt/GrossDomesticProduct6489022059004.pdf? blob=publicationFile

Federal Statistical Office / Statistisches Bundesamt (2013a): Finanzen und Steuern. https:/www.destatis.de/DE/Publikationen/Thematisch/FinanzenSteuern/ThemaFinanzen.html

Federal Statistical Office / Statistisches Bundesamt (2013b): Inlandsproduktsberechnung - Detaillierte Jahresergebnisse. Fachserie 18 Reihe 1.4 - 2012.

https://www.destatis.de/DE/Publikationen/Thematisch/VolkswirtschaftlicheGesamtrechnungen/Inlandspr odukt/InlandsproduktsberechnungVorlaeufigXLS_2180140.xls? blob=publicationFile 
German Council of Economic Experts (Sachverständigenrat zur Begutachtung der gesamtwirtschaftlichen Entwicklung) (2001): Für Stetigkeit - gegen Aktionismus. Jahresgutachten 2001/2002, Wiesbaden. http://www.sachverstaendigenratwirtschaft.de/fileadmin/dateiablage/download/gutachten/01_ges.pdf

German Council of Economic Experts (Sachverständigenrat zur Begutachtung der gesamtwirtschaftlichen Entwicklung) (2003): Staatsfinanzen konsolidieren - Steuersystem reformieren. Jahresgutachten 2003/2004, Wiesbaden. http://www.sachverstaendigenratwirtschaft.de/fileadmin/dateiablage/download/gutachten/03_ges.pdf

German Council of Economic Experts (Sachverständigenrat zur Begutachtung der gesamtwirtschaftlichen Entwicklung) (2006): Reform der Einkommens- und Unternehmensbesteuerung durch die Duale Einkommensteuer. Expertise im Auftrag der Bundesminister der Finanzen und für Wirtschaft und Arbeit vom 23. Februar 2005. Wiesbaden. http://www.sachverstaendigenratwirtschaft.de/fileadmin/dateiablage/Expertisen/Reform_der_Einkommens_und_Unternehmensbesteuerung_durch_die_Duale_Einkommensteuer.pdf

Gorter, Joeri, Ruud A. de Mooij (2001): Capital Income Taxation in Europe: Trends and Trade-Offs. CPB Special Publications 30. Centraal Planbureau - Netherlands Bureau for Economic Policy Analysis, Den Haag. http://www.cpb.nl/sites/default/files/publicaties/download/capital-incometaxation-europe-trends-and-trade-offs.pdf

Görzig, Bernd Claudius Schmidt-Faber (2001): Wie entwickeln sich die Gewinne in Deutschland? Gewinnaussagen von Bundesbank und Volkswirtschaftlicher Gesamtrechnung im Vergleich. Sonderhefte Deutsches Institut für Wirtschaftsforschung 171. Berlin: Duncker \& Humblot.

Heckemeyer, Jost H., Christoph Spengel (2008): Ausmaß der Gewinnverlagerung multinationaler Unternehmen - empirische Evidenz und Implikationen für die deutsche Steuerpolitik. Perspektiven der Wirtschaftspolitik 9, 37-61.

IFS London - Institute for Fiscal Studies (2005): Corporate tax rate data. http://www.ifs.org.uk/data/internationaltaxdata.zip

Jacobs, Otto H., Christoph Spengel (1999): The Effective Average Tax Burden in the European Union and the USA: A Computer-based Calculation and Comparison with the model of the European Tax Analyzer, ZEW Discussion Paper No. 99-54. ftp://ftp.zew.de/pub/zew-docs/dp/dp5499.pdf

Jacobs, Otto H., Christoph Spengel (2002): Effective Tax Burden in Europe. ZEW Economic Studies 15. Heidelberg: Physica.

Jonas, Bernd (2009): Das Volumen von Steuersubstratverlagerungen in Outbound-Fällen. In: W. Spindler et al. (eds.): Steuerzentrierte Rechtsberatung. Festschrift für Harald Schaumburg zum 65. Geburtstag. Köln: Schmidt, S. 793-812.

King, Mervyn A., Don Fullerton (1984): The Taxation of Income from Capital. Chicago and London: University of Chicago Press.

Luh, Thomas (1996): Verbesserung der statistischen Erfassung der Unternehmensgewinne zur Berechnung des Bruttosozialprodukts von der Einkommensseite. Band 3 der Schriftenreihe Spektrum der Bundesstatistik. Stuttgart.

OECD (1991): Taxing Profits in a Global Economy. Domestic and International Issues. Paris: OECD.

OECD (2005): Measuring Globalisation. OECD Economic Globalisation Indicators 2005. Paris: OECD.

OECD (2011): Corporate Loss Utilisation through Aggressive Tax Planning. OECD Publishing. http://dx.doi.org/10.1787/9789264119222-en

OECD (2012): Revenue Statistics 1965-2011. OECD Publishing.

http://dx.doi.org/10.1787/10.1787/rev_stats-2012-en-fr

OECD (2013): Addressing Base Erosion and Profit Shifting. OECD Publishing. http://dx.doi.org/10.1787/9789264192744-en

OECD Tax Database (2013): http://www.oecd.org/ctp/taxdatabase 
Oxford University Centre for Business Taxation (2012): CBT Tax Database.

http://www.sbs.ox.ac.uk/centres/tax/Documents/reports/Tax_database.xlsx, http://www.sbs.ox.ac.uk/centres/tax/Documents/reports/Tax_data_description.pdf

Office for National Statistics UK (200): UK ESA95 Gross National Income Inventory of Methods. http://www.ons.gov.uk/ons/rel/naa1-rd/gross-national-income-inventory-of-methods/uk-gross-nationalincome--esa95--inventory/index.html

Piotrowska, Joanna, Werner Vanborren (2008): The corporate income tax rate-revenue paradox: Evidence in the EU. Taxation Papers 12, Directorate General Taxation and Customs Union, European Commission.

http://ec.europa.eu/taxation_customs/resources/documents/taxation/gen_info/economic_analysis/tax_pape rs/taxation_paper_12_en.pdf

Plachta, Robert Christopher (2008): Schuldenfalle Finanzausgleich. Theoretische und empirische Analyse der deutschen Finanzverfassung. Dissertation, Wirtschafts- und Sozialwissenschaftliche Fakultät der Universität zu Köln. 2008. http://kups.ub.uni-koeln.de/volltexte/2009/2584/pdf/PlachtaDissertation.pdf

Ramb, Fred, Alfons J. Weichenrieder (2005): Taxes and the Financial Structure of German Inward FDI. Review of World Economics (Weltwirtschaftliches Archiv) 141, 670-692.

Ruding Report (1992): Report of the Committee of Independent Experts on Company Taxation, Luxembourg: Commission of the European Communities.

http://aei.pitt.edu/1332/1/ruding tax_report.pdf

Schaumburg, Harald (2006): Normative Defizite und internationale Verrechnungspreise. Der Konzern 2006, 495-502.

Sørensen, Peter Birch (2007): Can Capital Income Taxes Survive? And Should They? CESifo Economic Studies 53, 172-228. http://cesifo.oxfordjournals.org/cgi/content/abstract/53/2/172

Spengel, Christoph (2003): Internationale Unternehmensbesteuerung in der Europäischen Union. Steuerwirkungsanalyse, Empirische Befunde, Reformüberlegungen. Düsseldorf: IDW.

Spengel, Christoph, Christina Elschner, Michael Grünewald, Timo Reister (2007): Einfluss der Unternehmensteuerreform 2008 auf die effektive Steuerbelastung. Vierteljahrshefte zur Wirtschaftsforschung 76, 86-97. http://ejournals.duncker-humblot.de/doi/pdf/10.3790/vjh.76.2.86

Statistics Netherlands, National Accounts Department (2008): Gross National Income Inventory (ESA 95). http://www.cbs.nl/NR/rdonlyres/D6900700-8D0A-4E7E-B611A7906B94A77B/0/2009GROSSNATIONALINCOMEINVENTORYESA95pub.pdf

Statistics Sweden (2008): ESA95 GNI Inventory Sweden, Revision 4 - August 2008. http://www.scb.se/statistik/NR/NR0102/ESA95\%20GNI\%20Inventory_revAug2008.pdf

U.S. Department of Commerce, Bureau of Economic Analysis (2009): Concepts and Methods of the U.S. National Income and Product Accounts. October 2009.

http://www.bea.gov/national/pdf/NIPAhandbookch1-4.pdf

Wamser, Georg, Michael Overesch (2010): Corporate Tax Planning and Thin-Capitalization Rules: Evidence from a Quasi-Experiment. Applied Economics 42, 563-573.

Weichenrieder, Alfons (2009): Profit shifting in the EU: Evidence from Germany. International tax and public finance 16, 281-297.

Weichenrieder, Alfons J., Helen Windischbauer (2008): Thin-Capitalization Rules and Company Responses. Experience from German Legislation. CESifo working paper, No. 2456. https://www.econstor.eu/dspace/bitstream/10419/26501/1/589227882.PDF

Weichenrieder, Alfons J., Martin Ruf (2012): The Taxation of Passive Foreign Investment. Lessons from German Experience. Canadian Journal of Economics/Revue canadienne d'économique 45, 1504-1528. http://onlinelibrary.wiley.com/doi/10.1111/j.1540-5982.2012.01737.x/abstract 